\title{
The Risk Atlas of Mexico City, Mexico: A Tool for Decision-Making and Disaster Prevention
}

\section{David A. Novelo-Casanova ( $\nabla$ dnovelo@geofisica.unam.mx )}

Instituto de Geofisica https://orcid.org/0000-0002-8799-4006

\section{Gerardo Suárez}

Universidad Nacional Autonoma de Mexico Instituto de Geofisica

\section{Enrique Cabral-Cano}

Universidad Nacional Autonoma de Mexico Instituto de Geofisica

\section{Enrique A. Fernández-Torres}

Posgrado en Ciencias de la Tierra, Instituto de Geofisica, UNAM

\section{Oscar A. Fuentes-Mariles}

Universidad Nacional Autonoma de Mexico Direccion General de Bibliotecas: Universidad Nacional

Autonoma de Mexico

\section{Emre Havazli}

University of Miami Rosenstiel School of Marine and Atmospheric Science

\section{Miguel A. Jaimes}

Universidad Nacional Autonoma de Mexico Instituto de Ingenieria

\section{Erika D. López-Espinoza}

Universidad Nacional Autonoma de Mexico Centro de Ciencias de la Atmosfera

\section{Ana Lillian Martin-Del-Pozzo}

Universidad Nacional Autonoma de Mexico Instituto de Geofisica

\section{Wendy V. Morales-Barrera}

Universidad Nacional Autonoma de Mexico Instituto de Geologia

\section{Hipólito L. Moráles-Rodríguez}

Universidad Nacional Autonoma de Mexico Instituto de Ingenieria

\section{Amiel Nieto-Torres}

Universidad Nacional Autonoma de Mexico Biblioteca Conjunta de Ciencias de la Tierra: Universidad Nacional Autonoma de Mexico

\section{Sergio Rodríguez-Elizarrarás}

Universidad Nacional Autonoma de Mexico Direccion General de Bibliotecas: Universidad Nacional Autonoma de Mexico

\section{Darío Solano-Rojas}

Facultad de Ingeniería, Universidad Nacional Autónoma de México

\section{Victor M. Velasco-Herrera}

IGEF: Universidad Nacional Autonoma de Mexico Instituto de Geofisica 


\section{Research Article}

Keywords: Mexico City, Hazard, Vulnerability, Risk, Risk Atlas, Disaster Prevention, Mexico

Posted Date: June 1st, 2021

DOl: https://doi.org/10.21203/rs.3.rs-548495/v1

License: (c) (1) This work is licensed under a Creative Commons Attribution 4.0 International License. Read Full License

Version of Record: A version of this preprint was published at Natural Hazards on October 8th, 2021. See the published version at https://doi.org/10.1007/s11069-021-05059-z. 
THE RISK ATLAS OF MEXICO CITY, MEXICO: A TOOL FOR DECISIONMAKING AND DISASTER PREVENTION

\author{
David A. Novelo-Casanova ${ }^{1 *}$, Gerardo Suárez ${ }^{1}$, Enrique Cabral-Cano ${ }^{2}$, Enrique A. \\ Fernández-Torres $^{3}$, Oscar A. Fuentes-Mariles ${ }^{4}$, Emre Havazli ${ }^{5}$, Miguel Á. Jaimes ${ }^{6}$, \\ Erika D. López-Espinoza ${ }^{7}$, Ana Lillian Martin-Del-Pozzo ${ }^{8}$, Wendy V. Morales- \\ Barrera9 $^{9}$, Hipólito L. Morales-Rodríguez ${ }^{4}$, Amiel Nieto-Torres ${ }^{3}$, Sergio Rodríguez- \\ Elizarrarás ${ }^{9}$, Darío Solano-Rojas ${ }^{10}$, Victor M. Velasco-Herrera ${ }^{11}$ \\ ${ }^{1}$ Departamento de Sismología, Instituto de Geofísica \\ ${ }^{2}$ Departamento de Geomagnetismo y Exploración, Instituto de Geofísica \\ ${ }^{3}$ Posgrado de Ciencias de la Tierra, Instituto de Geofísica \\ ${ }^{4}$ Coordinación de Hidráulica, Instituto de Ingeniería \\ ${ }^{5}$ University of Miami, Rosenstiel School of Marine and Atmospheric Science, 4600 \\ Rickenbacker Cswy, Miami, FL 33149, USA \\ ${ }^{6}$ Coordinación de Ingeniería Estructural, Instituto de Ingeniería \\ ${ }^{7}$ Departamento de Ciencias Atmosféricas, Centro de Ciencias de la Atmósfera \\ ${ }^{8}$ Departamento de Vulcanología, Instituto de Geofísica \\ ${ }^{9}$ Departamento de Dinámica Terrestre Superficial, Instituto de Geología \\ ${ }^{10}$ Facultad de Ingeniería \\ ${ }^{11}$ Sección de Radiación Solar, Instituto de Geofísica \\ 1, 2, 3, 4, 6, 7, 8, 9, 10,11 Universidad Nacional Autónoma de México, Col. Ciudad Universitaria, \\ Alcaldía Coyoacán, Ciudad de México 04510, México
}

* Corresponding author: E-mail: dnovelo@geofisica.unam.mx; Tel: (5255) 5622 4127, Ext. 149. 


\begin{abstract}
We present a Geographical-Information-System-based Risk Atlas (GIS-RA) of Mexico City, Mexico. The main purposes are to provide a local-government level tool for implementing preventive and remedial actions useful for land-use development plans and to strengthen the culture for disaster prevention. We identified the prevalent social risk to the more relevant hazards in Mexico City (CDMX): earthquakes, volcanic eruptions, floods, landslides, forest fires, and land subsidence. A total of 274 shape-file maps were generated in this project. Seismic hazard was estimated for return periods (RP) of 20, 125, 250, and 475 years. Three areas in central and northwestern CDMX were identified along the Younger Chichinautzin Monogenetic Volcanic Field with high probability of forming a new volcano. Subsidence is concentrated to the east and southeast of CDMX, where subsidence rates are among the highest worldwide. Flooding events were estimated for RP of 2, 5, 10, 50 and 100 years and the majority of them are concentrated in the central and northern sectors of the city. During the dry season (December-April), southern CDMX has very high probability of forest fire occurrence. There is high susceptibility of landslides on the west and southwest of the city. The goals of this GIS-RA are to: 1) improve the knowledge of the potential impact of local hazards; 2) provide elements for disaster prevention, mitigation, preparedness, and response; 3) benefit decision-makers with robust risk data; 4) provide information for land-use planning; and 5) support further research to reduce the impact of disasters.
\end{abstract}

Key words: Mexico City, Hazard, Vulnerability, Risk, Risk Atlas, Disaster Prevention, Mexico. 


\section{Introduction}

The United Nations (2016) estimated that about 55\% of the world's population is concentrated in urban areas and that many are highly exposed to natural hazards (Gencer 2013). Mexico City (CDMX), Mexico, is one of the larger cities in the world; its urban development has been explosive and, in many cases, unplanned (García-Acosta 2006). In this respect, CDMX represents a showcase of a megalopolis that is highly exposed to disasters.

The reason behind Mexico City's high level of exposure to natural phenomena lies at the core of its history. Mexico City sits in an endorheic basin where precipitation formed a set of interconnected lakes fed by rivers flowing from the surrounding mountains (Santoyo et al. 2005; Sosa-Rodríguez 2010). CDMX was founded on the remains of the old Aztec capital. The Aztecs built their city on an island in the middle of a lake. After the Spanish conquest, the Spaniards decided to build the new capital on the ruins of the old Aztec city and began to drain and landfill the surrounding lakes. They also disregarded maintenance of the system of dikes and aqueducts built by the original inhabitants to control flooding (Levi 1990; Sosa-Rodríguez 2010). As a result, the newly founded city suffered frequent inundations in 1555, 1604, 1607 and 1629 (Hoberman 1974). After the 1607 catastrophic floods, the authorities ordered the construction of a channel to the northeast of the city to drain the lakes and to provide an outlet during heavy rains (Boyer 1975; Scaletti Cárdenas 2018).

Since those early days, major engineering projects have been undertaken to alleviate flooding of the city. Most of the original lakes have been drained and CDMX gradually grew on the soft clay sediments of the old lakebed. This soft, water-saturated subsoil is the cause behind many of the hazards now faced by the city. For example, although CDMX lies about $350 \mathrm{~km}$ from the subduction zone where the largest and more frequent earthquakes originate, it is severely affected by strong shaking due to the local amplification of seismic waves (e.g. Ordaz and Singh 1992). Also, the subsidence rates observed in CDMX, considered to be among the largest in the world, are due to the sinking of the lakebed due to 
water extraction (López-Quiroz et al. 2009; Cabral-Cano et al. 2008; Osmanoglu et al. 2011). Additionally, soil fractures result from the differential subsidence of the ground (Auvinet et al. 2013).

As a result of the subsoil characteristics of CDMX, the population, infrastructure, and critical facilities are highly exposed to hazards such as earthquakes, land subsidence and flooding. In addition, CDMX is located in the Trans Mexican Volcanic Belt (TMVB) and affected by volcanic activity. Thus, CDMX faces important challenges to contend with future disaster situations. Digital maps are important interactive tools to visualize and compare the spatial distribution of the population, buildings, and infrastructure exposed to various hazards. In this manner, hazards and exposed areas are readily identified and crossreferenced.

The purpose here is to present a digital Atlas of hazards and social risk of CDMX developed in a Geographic Information System that from now on we name GIS-RA. Also, because risk is a spatially dependent phenomenon, emergency managers and the general public require a proper visualization instrument such as a GIS. The main objectives of the GIS-RA are to make authorities, citizens and the media aware of the levels of natural hazards and risks to which the city is exposed with the purpose of providing the necessary elements to establish preventive and remedial actions. This GIS-RA can also serve as a guide for future land use and development plans, to promote scientific research on the subject and to strengthen the culture of disaster prevention in society.

Here we present the methodologies used to assess hazard, social vulnerability, and risk at the scale of CDMX and several examples of the studies and maps that constitute the GISRA. We also include an electronic supplement that shows the hazard, vulnerability, and risk maps in PDF format generated or updated during the course of this research (Online Resource 1). 


\section{Development of Hazard Reduction Efforts in Mexico City and the Risk Atlas}

After the destructive earthquake of 19 September $1985\left(M_{w}\right.$ 8.1) (UNAM Seismology Group 1986), the Mexican authorities promoted various initiatives to build a nation-wide civil protection system to prevent disasters caused by natural phenomena and anthropogenic activity. Important early contributions were the creation of the National Civil Protection System (SINAPROC) in 1986 and the Mexican National Center for Disaster Prevention (CENAPRED). Also, the installation of civil protection offices was mandated at all levels of government.

An additional response was the development of the Seismic Early Warning System in 1989. Given the location of the city, large earthquakes in the subduction zone allow approximately 60s of warning before the arrival of damaging seismic waves (EspinosaAranda et al. 1995; Suárez et al. 2009, 2018). Although these initiatives have achieved considerable progress, the local authorities recognized the need to continue improving disaster risk management based on preventive actions. As part of these efforts, the Secretariat of Education, Science, Technology, and Innovation (SECTEI) of the Mexico City government funded the present project to develop the GIS-RA. In this first phase, the main purpose is to identify the levels of hazard associated to earthquakes, volcanic eruptions, floods, landslides, forest fires, and land subsidence. Social vulnerability is also evaluated to estimate the risk posed by these natural hazards.

\section{Earthquake Hazard}

Mexico has a long history of destructive earthquakes (García-Acosta and Suárez 1996). Although the 19 September $1985\left(M_{w} 8.1\right)$ earthquake was located $\sim 350 \mathrm{~km}$ away from CDMX, the city suffered considerable damage and loss of life (Aguilar et al. 1989; Rosenblueth and Meli 1986; UNAM Seismology Group 1986; Stone et al. 1987). Earthquakes along the subduction zone are not the only seismic sources that have affected CDMX in the past. The city is also vulnerable to earthquakes located beneath the continent that reflect the deformation of the subducted Cocos plate. The more recent example occurred on 19 September 2017, when an intraplate earthquake $M_{w} 7.1$ was strongly felt by 
several communities in Mexico including CDMX. Its epicenter was located $\sim 150 \mathrm{~km}$ from the city at a depth of $55 \mathrm{~km}$. In Mexico City, more than 40 buildings collapsed, and 370 people perished.

An additional source of seismic hazard is represented by the crustal faults located on the Trans-Mexican Volcanic Belt (TMVB). Two large crustal earthquakes took place in the TMVB in the early $20^{\text {th }}$ century: the Acambay earthquake of 19 November $1912\left(M_{w} 6.9\right)$ (Urbina and Camacho 1913) and the Xalapa event of 4 January $1920\left(M_{w} 6.4\right)$ (Flores and Camacho 1922; Suárez and Novelo-Casanova 2018). Several other damaging crustal earthquakes have taken place also in the TMVB during the past 450 years (Suárez et al. 2019). The Atlas presented here also shows the risk posed by this type of earthquakes to buildings in CDMX (Online Resource 1).

\subsection{Seismic micro zonation}

The CDMX building code classifies the local soil conditions into three seismic zones (Gobierno del Distrito Federal 2004): Zone I (Hill zone) constituted mainly of basaltic and rhyolitic lava and compact pyroclastic flows; Zone II (Transition zone) composed of sands and pyroclastic material from the surrounding volcanic deposits; Zone III (lakebed zone) composed of silt and volcanic clay sediments with a very high water content that suffer large ground amplification with passing seismic waves (Ordaz and Singh 1992; Lermo and Chávez-García 1994). Zone III is subdivided further into three zones. The stark contrasts of the geotechnical conditions of the soil in CDMX shows that micro zonation based on the natural period of the ground is an essential element in the evaluation of seismic hazard and in the design of building codes and regulations.

To update the spatial seismic response of the CDMX's subsoil we used the spectral ratio technique developed by Nakamura (1989). It is considered that this spectral technique gives an approximation of the soil's transfer function, its amplification, and the natural period of vibration (Bard 1999). We used the following data to construct the microzonation maps: a) new measurements made in 75 sites (Figure 1); b) records from 84 sites, previously obtained by different authors; and c) recordings from 53 stations of the Accelerographic 
Network of Mexico City (RACM), operated by the Instrumentation Center and Seismic Recording (CIRES; Centro de Instrumentación y Registro Sísmico, in Spanish). A total of 212 recordings were interpolated using a thin plate spline (Duchon 1977). As expected, the results confirm that the lakebed zone of CDMX is where seismic amplification is very high (Figure 1).

\subsection{Evaluation of Seismic Hazard}

Seismic hazard in CDMX was estimated for return periods prescribed by CENAPRED of 20, 125, 250, and 475 years. The methodology considers the following steps (Jaimes and Niño, 2017): a) characterization of the different seismic sources potentially affecting CDMX (subduction, intraslab, and crustal) (Figure 2); b) use of the appropriate ground motion models depending on the types of earthquakes that each seismic source may generate such as interplate, intermediate, and shallow crustal depth (Abrahamson and Silva 1997; Jaimes et al. 2006, 2015; Jaimes and García-Soto 2020); c) convolution of the response spectral ratios (soil transfer functions between each instrumented and reference sites; Rosenblueth and Arciniega 1992) with the ground motion predictions; and d) probability estimation of shaking intensity (e.g., peak ground acceleration, or spectral pseudo-acceleration corresponding to the first-mode period of vibration) for the different return periods.

There is a univocal correlation between the thickness of the soft and water-saturated clays and the areas where the probability of high peak ground acceleration is observed. Areas of the cities in the central part of the ancient lakes are the more heavily impacted by soil amplification. The PGA values in the lakebed zone (Zone III) vary from a possible maximum $0.09 \mathrm{~g}$ for a return period of 20 years (Figure $3 \mathrm{a}$ ) up to $0.53 \mathrm{~g}$ for 475 years (Figure 3d). These areas are concentrated in municipalities located in the central, southern, and eastern zones of the city (Figure 3). Seismic hazard for other intensity measures such as spectral accelerations were also computed. 


\section{Volcanic Hazard in Mexico City}

\subsection{Eruption of a new volcano in the Younger Chichinautzin Monogenetic Field}

CDMX lies in the Trans Mexican Volcanic Belt, an active Miocene to recent geological structure that spans central Mexico from the Pacific Ocean to the Gulf of Mexico (e.g., Ferrari et al. 2012). Unlike most volcanic arcs associated with subduction processes, the TMVB is oblique and not parallel to the trench where the Cocos and Rivera plates subduct beneath North America (Pardo and Suárez 1995). In this geological context, the history of CDMX is strongly tied to surrounding volcanoes and it is also exposed to hazards presented by the surrounding volcanic structures.

One of these volcanic hazards stems from the Younger Chichinautzin Monogenetic Field (YCMF). This is a volcanic structure to the south of CDMX that is of particular interest due to its very young age and its potential impact on the city. Historical eruptions of the YCMF occurred at a time when the region was sparsely inhabited (Martin-Del-Pozzo 1982; Córdoba et al. 1994; Martin-Del-Pozzo et al. 1997). Radiocarbon dates for the Xitle volcano eruption range from $1670 \pm 35$ to $2030 \pm 60 \mathrm{BP}$. The lava flows covered an area of $70 \mathrm{~km}^{2}$ in southern CDMX burying the Cuicuilco constructions (Martin-Del-Pozzo et al. 1997; Siebe 2000). Later, the Chichinautzin volcano erupted in 1835 BP covering a very large area of southern CDMX (Martin-Del-Pozzo et al. 1997). Clearly, a new eruption in this region would have devastating consequences for the population and infrastructure of CDMX. In order to extend the existing studies of volcanic hazard in CDMX, we incorporated the recent work of Nieto-Torres and Martin-Del-Pozzo (2019) and NietoTorres (2020), who estimated probabilistically the hazard associated to the eruption of a new volcano in YCMF.

The volcanic activity of the YCMF was analyzed to probabilistically forecast future eruptions assuming that this potential activity would follow a similar pattern in time as past volcanic eruptions. To this end, the monogenetic volcanoes of the YCMF were dated based on morphometric analysis (Wood 1980; Martin-Del-Pozzo 1982; Hooper 1995). Wood (1980) proposed that the rate between the volcano's height $(H)$ and width $(W)$ is a rough 
indicator of the volcano's age. Thus, $H / W$ is higher for relatively young volcanoes than for older ones. This rate is called the volcano's youth index $\left(I_{j}\right) . I_{j}$ parameters were measured from multispectral images, topographic maps, digital elevation model (DEM), and from fieldwork in the area. Nieto-Torres (2020) and Nieto-Torres and Martín Del Pozzo (2019) used the ages of the volcanic edifices to determine a probability function for future eruptions of the YCMF in a $5 \times 5 \mathrm{~km}$ grid.

Based on a Grid Probability Analysis (Song et al. 2013), three areas (A, B, C) located close to the volcanoes with the most recent eruption history, were identified to have a high probability of generating a new volcano in the YCMF (Figure 4a). The results of the analysis show that there is 0.99 probability that a new eruption could take place in a 2,000year window for the whole YCMF. This value agrees with the observation made by Siebe et al. (2004) who suggest that eruptions in the YCMF have recurrence rates of $\sim 1,700$ years. The hazard posed by this field of monogenetic volcanoes is highlighted by the fact that the last eruption took place 1,670-2030 years BP.

Lava flows from each of these A, B, and C volcanic zones were modeled to estimate their potential thickness and areal span (Nieto-Torres 2020). This modeling was performed using the Etna Lava (Damiani et al. 2006) and the Q-LAVHA models (Mossoux et al. 2016) (Figure 4b). For an eruption in Zone A, the resulting scenario consisted of fluid lavas, $5 \mathrm{~m}$ thick with a distance range of $12 \mathrm{~km}$; this scenario is similar to past volcanic activity of Xitle volcano (Nieto Torres and Martin-Del-Pozzo 2019). In Zone B, viscous lavas with a thickness of about $150 \mathrm{~m}$ and a distance range of $5 \mathrm{~km}$ were modeled, considering that the eruption would be similar to those from the neighboring Xicomulco volcano (Nieto-Torres 2020). In the expected scenarios for Zone C, eruptions would produce fluid lava flows with thickness on the order of $3 \mathrm{~m}$ and travel distances in the range of $15 \mathrm{~km}$ (Nieto-Torres 2020).

The scenario for zone A would extend deep into central CDMX. Scenarios for zones B and $\mathrm{C}$ would affect southern and southeastern sectors of the city, respectively (Figure 4b). The 
scenario for zone $\mathrm{C}$ would also impact the community of Tepoztlán in the state of Morelos, to the south of CDMX (Figure 4b).

Nieto-Torres (2020) also modeled the spatial distribution of ash fall for volcanic eruptions in zones A and C using the software Tephra (Courland et al. 2012). Ash fall for an eruption in region $\mathrm{B}$ was not considered because in this area previous volcanic activity consisted mainly of lava efussion. Nieto-Torres (2020) ash fall scenarios would result in a large number of exposed elements in CDMX (population, houses, critical infrastructure). Also, about $27 \mathrm{~km}^{2}$ of agricultural and $23 \mathrm{~km}^{2}$ of forested areas would be impacted. Primary communication routes in CDMX would be exposed also and could delay the delivery of materials and medical supplies, as well as the operation of basic services such as banks, gas stations, hotels, self-service stores, airports, etc. Additionally, these ash deposits would cause health and sanitary effects.

\section{Subsidence of the Ground in CDMX}

Land subsidence is generally related to the consolidation of fine-grained materials in response to effective stress increments caused by the extraction of fluids from underground compressible soil (Galloway and Burbey 2011; Herrera et al. 2021). Subsidence in CDMX is a major hazard due to the intensive water extraction rates from its underlying lacustrine, water-saturated sediments. Ground subsidence was first reported in CDMX in the early $20^{\text {th }}$ century. It is estimated that parts of CDMX have subsided as much as nine meters since the mid $19^{\text {th }}$ century (Gayol 1925; Carrillo 1948).

In the past decade, subsidence of the city has been studied with modern geodetic techniques (Cabral-Cano et al. 2008; López-Quiroz et al. 2009; Osmanoglu et al. 2011; Chaussard et al. 2014; Du et al. 2019; Fernández-Torres et al. 2020; Solano-Rojas et al. 2020; Cigna and Tapete 2021). In this study, subsidence in CDMX was analyzed using 125 images recorded between November 2014 and October 2017 by the C-band SAR (Synthetic Aperture Radar) instrument onboard the Sentinel 1-A and B in Interferometric Wide Swath, descending mode (Figure 5a). The dataset was processed using the ISCE software (Rosen et al. 2012) 
to generate interferometric pairs and SBAS time-series using the program MintPy (Yunjun et al. 2019). Following Osmanoglu et al. (2011), the former GPS site UCHI was used as the reference point along with stations UTUL and UFXN that are part of the TLALOC Net GPS network (Cabral-Cano et al. 2008) for further validation and inter-comparison with previous analysis using other SAR sensors.

The zones with very high subsidence rates of more than $25 \mathrm{~cm} / \mathrm{yr}$ (line of sight) are concentrated towards the northeast, southeast, and east of CDMX (Figure 5a). In some cases, these large subsidence rates have resulted in fractures.

\subsection{Horizontal Subsidence Gradient}

A horizontal subsidence gradient (HSG) was also determined based on the subsidence results. This measure is a useful proxy for detecting areas with the potential to generate fractures and faults due to differential subsidence (Cabral-Cano et al. 2008; 2015). Our results are presented within the spatial framework of the Basic Geo-statistical Areas (AGEB) in order to better estimate the exposed population and for civil protection purposes. An AGEB is defined by the Mexican Institute of Geography and Statistics (INEGI) as a basic geographic area where a group of city blocks (1-50) are well delimited by streets and avenues or any other easily identified urban feature where the land use is mainly for housing, industry, commerce, and other urban services.

Based on the AGEB spatial distribution, three regions with large HSG (0.014-0.024\%) were identified mainly to the east of CDMX (Figure 5b). These high-gradient zones are located on the abrupt transition between lacustrine sediments undergoing subsidence and the stable volcanic rocks (Cabral-Cano et al. 2008; 2015). In these areas, considerable differences in relative vertical motion develop over short distances, resulting in high horizontal strain and surface faulting development that eventually fracture building walls, columns and beams (Burland et al. 2004). 


\subsection{Angular distortion}

Angular distortion $(\beta)$ is the ratio of the differential subsidence $(\delta)$ between two surface points located at a distance $(L)$ (Ricceri and Soranzo 1985). It is simply expressed as:

$$
\beta=\delta / L
$$

Skempton and Macdonald (1956) proposed expected levels of damage due to angular distortion variations based on studies throughout the world (United Kingdom, Austria, Brazil, The United States, Mexico) (Table 1). These values should be a reference for construction design (Meyerhof 1956; Bjerrum 1963; Wahls 1981).

The angular distortion map of CDMX is based on the HSG vertical displacements (Fernández-Torres et al. 2020). For a clear representation of a worst-case scenario, we assigned the maximum HSG value to each of CDMX's AGEBs (Figure 5c). As expected, the higher angular distortion rates (> 0.008 radians) are observed in the municipalities located to east of the city, near the boundary between the soft soils and the volcanic terrains (Figure 5c).

\section{Floods}

As discussed before, floods have accompanied the history of Mexico City since its foundation. Despite of the intensive and ambitious engineering projects undertaken to drain CDMX during periods of heavy rain, the closed nature of the basin coupled to the continued land subsidence induced by water extraction of the subsoil create permanent danger of flooding in several parts of the city.

\subsection{Return period and volume}

To estimate the return period of floods in CDMX we analyzed the hydrological characteristics of the greater Metropolitan Zone of the Basin of Mexico (MZBM) that extends beyond the political boundaries of CDMX and was geographically divided into 250 
regions "tributary stream areas" that were determined considering the local topography, land use, and drainage (Figure 6a). The precipitation data from pluviometric stations were obtained from the Mexican National Water Commission (http://clicom-mex.cicese.mx) for the period 1920 to 2015 .

The analysis was restricted to historical records comprising twenty or more years and with complete daily rain datasets for the months from June to October, the rain season in Mexico City. For each selected station we obtained the maximum rainfall per year and a frequency analysis was performed using the software $A x$ developed by CENAPRED that allows the estimation of probability functions for temporal series (Jimenez 1996).

The effective rainfall was obtained multiplying the rainfall sheet for a specific return period by the runoff coefficient of each tributary area considering the type of soil and land use (Goel 2011):

$$
h_{e}^{T r}{ }_{i}=h_{i}^{T r} C_{e_{i}}
$$

Where:

$i=1,2,3, \ldots, 250$ : Identifies the tributary area.

$h_{i}^{T r}$ : Rainfall sheet for the tributary area $i$ and the return period $T_{r}$. $C_{e_{i}}$ : Runoff coeffficient for tributary area $i$.

$h_{e}^{T r}{ }_{i}: E$ ffective rainfall sheet $(\mathrm{m})$ for the tributary area $i$ with return period $T_{r}$.

The flood volume for each tributary area $\left(V_{i n d_{i}}^{T r}\right)$ was obtained by multiplying the effective rainfall sheet for a determined return period $\left(h_{e}^{T r}{ }_{i}\right)$ by the area of the tributary area $\left(A_{i}\right)$ (Goel 2011):

$$
V_{\text {ind }}^{T r}=A_{i} h_{e}^{T r}
$$

Flooding in urban areas occurs when the local drainage is unable to dispose of all rainfall. Assuming that the flood volume in each tributary area is concentrated in zones of low 
topographic elevation in a hemisphere (Figure 6b), the water volume was estimated from the following equation:

$$
V_{i n u}=\frac{\pi h^{2}}{3}(3 r-h)
$$

Where:

$$
\begin{aligned}
& V_{i n u}: \text { Flood's volume }\left(\mathrm{m}^{3}\right) \\
& h \text { : Flood's height }(\mathrm{m}) \\
& r \text { : Hemisphere's radius }(\mathrm{m}) .
\end{aligned}
$$

To estimate the water mirror's area $(A)$ and the flood's radius ( $a$ ) (Figure 6b), we used the following equations:

$$
\begin{gathered}
A=\pi a^{2} \\
a^{2}=2 r h-h^{2}
\end{gathered}
$$

\subsection{Flood area}

The flood areas were estimated using the following data:

a) The water volume database obtained following the procedures described above for each tributary area.

b) The vector data of each tributary area.

c) The DEM of CDMX.

With this information, the procedure to estimate the flood area is as follows:

Step 1: Flood heights were calculated considering the water volumes resulting from the different return periods analyzed. Using the DEM of CDMX, a 3D elevation model was determined with topographic contours every $0.10 \mathrm{~m}$. Based on these data and using the "Polygon Volume" function of ArcGis10.3, we computed the water volume for a specific 
tributary area. These procedures were repeated until the theoretical volume (described above) was reached for the return periods considered. The topographic contours that contain the estimated volume provide the most probable zones that could potentially be flooded in the MZMV.

Step 2. With the tool Extract by Mask of ArcGis10.3, the raster of the flooding area was extracted and a new classification of the flood height was estimated considering five levels of hazard (Table 2).

Following these procedures, floods in CDMX were estimated for return periods of 2, 5, 10, 50, and 100 years, as established by CENAPRED (Figure 7). The majority of the potential flood areas in MZMV are concentrated in the central and in the northern part of its territory. This is coincident with the flood inventory for the period 1920-2017 compiled as part of this project (Online Resource 1).

The explosive urban growth has dramatically enlarged the impervious zone in Mexico City and increased the volume of rainwater that must be drained out of the basin. In many cases, the local drainage network is insufficient for this task. This situation leads to recurrent large flooding causing serious urban damage in CDMX. It is also important to point out that rainwater is frequently mixed with sewage from the local drainage network, which affects further the inhabitants of this metropolis.

\section{Forest fires}

The Mexican National Forest Commission (CONAFOR) installed in 1999 an Early Warning System (EWS) to alert for forest fires. This EWS is designed to evaluate and reduce the hazard represented by these fires. It is based on measurements of temperature, relative humidity, precipitation, and wind velocity. Using an index based on the initial propagation velocity and available fuel, the CONAFOR's EWS provides a meteorological index for fire hazard (http://forestales.ujed.mx/incendios/inicio/evolucion_del_peligro.php\#). 
In this project, the forest fire EWS was extended to forecast fires in the long term with the purpose of supporting local authorities in the development of preventive actions to reduce risk to the exposed population. We used satellite data from the NASA's Fire Information for Resource Management System (FIRMS) (https://firms.modaps.eosdis.nasa.gov/active_fire/\#firms-shapefile) for the period 2000 to 2019. This database provides fire hotspots locations, including coordinates, temperature, brightness, and resolution.

Fire hazard estimations are based on the Clustering Machine Learning tool to group temperature and brightness in clusters (Buduma and Locascio 2017). For our calculations, we used the algorithm boasted trees to analyze cluster data (Maloof 2005). This algorithm identifies groups of similar objects and establishes the pattern distribution of large datasets. Decision trees are machine-learning tools where each tree is dependent of previous trees. The algorithm "learns" continuously by fitting the residual of preceding trees. Gradient Boosting Tree algorithms perform well with unbalanced data such as those for wildfire risk assessments (Maloof 2005).

Following the procedures described above, we estimated for the western and southern regions of CDMX, the probability of fire occurrence during the rain and dry seasons for the next five years for the western and southern regions of CDMX (Figures 8a, 8b). During the rain season (May-November), there is moderate probability (41-60\%) of forest fires south of CDMX for the next five years (Figure 8a). However, during the dry season (DecemberApril), southern CDMX has high probability of forest fires (> 81\%) (Figure 8b). This is due to the forests located in the Tlalpan, Xochimilco, and Tláhuac municipalities (Figure 8).

Using the Machine Learning tool, we also forecast the number of expected forest fires up to the year 2028 (Figure 8c). We estimated that during the year 2025, there is a high probability that about 1400 forest fires would occur in CDMX (Figure 8c). This number is higher than the number of previous forest fires during the 1970-2020 periods. This forecast is based on the decadal periodicity of wildfires in CDMX. Our model predicts that in 2020 a new high-forest fire season initiated and that it will reach its peak around 2025. 


\section{Landslide Hazards in Mexico City}

The explosive growth of CDMX has led to the occupation of mountainous slopes that surround de flat metropolitan area. Several municipalities of CDMX are located on the volcanic deposits that form the Las Cruces, Guadalupe, and Chichinautzin (LCGC) ridges to the west and southern areas of the city. These volcanic edifices constitute the limits of the lacustrine basin. Besides the natural instability associated with the steep slopes of the terrain, land alteration due to urban growth and erosion has increased the susceptibility for the occurrence of Mass Movement Processes (MMP) such as landslides and rock falls. In addition, several communities in these zones are irregular settlements, increasing the exposure to MMP of a large fraction of the population of CDMX.

As a first step to estimate landslide susceptibility, we generated an inventory of landslides in CDMX for the period 1972 to 2018. The database was constructed from local newspapers reports, the Internet platform Desinventar (https://www.desinventar.org), and information provided by municipalities of CDMX. Desinventar is a tool containing data of human and material losses, damages, disasters, and events that have impacted different countries in Latin American and the Caribbean. Our inventory included the location, date of occurrence, size, typology, and damages associated to MMP. However, this information is not available for some events. In many cases, landslide locations were approximated considering the information gathered in the places impacted by this phenomenon (Figure 9).

We recorded more than 100 landslides in the inventory and as expected, most of them occurred during the rain season, from May to November. The majority of these events are concentrated in the western part of CDMX. However, some MMPs are also reported around the hills located in the eastern region of the city. MMP activity is mainly due to the geomorphic features of LCGC and the Santa Catarina Range (Figure 9).

The landslide susceptibility in CDMX was determined from fieldwork, interpretation of satellite images, analysis of samples in the laboratory, and from the municipal inventories. 
We considered five basic parameters: geology, slope, relative height, land use and type of vegetation. We used a DEM of $5 \mathrm{~m}$ resolution to generate the hypsometric and slope maps. Using the univariate statistical method (Denis 2020), and after testing different weights to identify those with less uncertainty for different scenarios, we weighed each of these parameters according to their assumed importance for a landslide to occur (Table 3). Also, each variable within each parameter was weighed considering relative values from 1 to 5 to indicate how much that variable increases the landslide susceptibility (Table 4). The results were classified in five categories of susceptibility (Figure 9): Very Low, Low, Moderate, High, and Very High.

The consequences of the development of settlements in the unstable mountainous areas of CDMX have resulted in damage and loss of human lives during the last 50 years (GarcíaPalomo et al. 2006). The results of this study should help to support preventive actions and land use policies designed to avoid catastrophes associated to MMP identifying areas that are inadequate for human settlement. In addition, the hazards associated to MMP processes have an important economic impact because they require constant resources for building or maintaining retaining walls and other engineering works to reduce the levels of risk.

\section{Social Vulnerability of CDMX}

Social vulnerability represents the collection of social traits and circumstances that make a community susceptible to be damaged by the impact of a particular hazard. It is an intrinsic characteristic of society that is independent of its exposure to natural and man-made hazards. However, social vulnerability is the most complicated component of risk to measure. This is because the concept is given varying interpretations and conceptual frameworks by different authors (Cutter et al. 2003; Rashed and Weeks 2003).

In this work, we consider thirteen indicators that reflect the social characteristics of the population, such as age, access to basic services (electricity, water, drainage, etc.), income, educational level, etc. (see Table 5 for the complete list). Each of these indicators is weighed using the Hierarchical Analytical Process (HAP) (Saaty 1980). The HAP was 
applied to the indicators in agreement with the opinion of experts from CENAPRED and from the authors of this work (Table 5). In the case of CDMX, the parameters given larger weights are population density, access to information, level of education, and availability of basic services (Table 5). The indicators were obtained from the 2010 Mexican Census of Population and Housing (Instituto Nacional de Estadística, Geografía e Informática 2010; https://www.inegi.org.mx/programas/ccpv/2010/). The resulting social indicators are mapped at the AGEB level to determine the spatial distribution of the social vulnerability $(S V)$ in CDMX (Table 5) as follows:

1) For each AGEB in CDMX we determined the proportional contribution of the following indicators: $S V_{1}, S V_{2} \ldots$ to $S V_{13}$ ) (Table 5).

2) $S V_{5}$ reflects the average of completed education years within each AGEB.

3) $S V_{10}$ reflects the population density and it is estimated as the ratio of the number of inhabitants and the area of each AGEB.

4) $S V$ is then calculated using the following equation:

$$
S V=\sum_{i=1}^{13} S V_{i} * w_{i}
$$

Where $w_{i}$ are the weights obtained using the HAP methodology (Saaty 1987; Table 5). Using equation (7) the social vulnerability of CDMX was classified into five levels: Very Low, Low, Moderate, High, and Very High, by applying the Jenks Natural Breaks classification of the ArcGIS10.3 (Figure 10). Jenks (1967) pointed out "This technique classifies data by optimizing the set of values into "natural" groups. This process is executed by reducing to a minimum the average deviation from the class mean, while maximizing the deviation from the means of the other groups." Our results show that social vulnerability varies between moderate and very high in the north, northeast, east, and central regions of CDMX (Figure 10). Unfortunately, more than half of the population of CDMX has a level of social vulnerability that varies between moderate and very high. Although we use several social parameters in our analysis, it is clear that social vulnerability in CDMX is closely tied to the average socioeconomic level of the population and the areas where they live. 


\section{Exposure}

Exposure refers to the people, communities and their assets that are predisposed to a particular hazard. We determined the level of exposure by overlaying the GIS layers of population and critical facilities over the different hazard layers analyzed in this research. The following exposed elements were considered: population, public schools (elementary, high school, college-university), hospitals, markets, fuel and radio stations, free connectivity sites (free internet places), and TV stations. This study reveals a very high level of exposure of a large fraction of the population and of critical infrastructure in CDMX (Online Resource 1).

\section{Social Risk}

Risk measures the probability of damage taking into account the combination of three factors: hazard, vulnerability, and exposure (Crichton 1999; Cutter et al. 2003). In this work, risk is expressed using a qualitative spatial multi-criteria evaluation technique by superimposing the raster of the social vulnerability over individual hazard rasters. The resulting values measure the "likelihood of risk". Vulnerability and hazard are classified into five categories, with values from 1 to 5. As a result, a meshing array reflects the likelihood of social risk for specific hazards (Figure 11). Under these considerations, the minimum and maximum values of risk are: $1(1 * 1)$ and $25(5 * 5)$ (Figure 11). Finally, risk is classified according to Table 6 and its spatial distribution is obtained using a Kriging spatial interpolation method (Burrough and McDonnell 1998).

Following these procedures, large extensions towards northeast and east of CDMX show moderate to high levels of social risk due to subsidence (Figure 12a). On the other hand, seismic social risk also varies from moderate to high in the central as well as the eastern and northeastern region of CDMX (Figure 12b). 


\section{Examples of Seismic risk scenarios}

As an integral part of the Risk Atlas of CDMX, we developed eight seismic risk scenarios (See maps in Online Resource 1). Scenarios 1 and 2 are similar to the 19 September 2017 and 17 September 2017 earthquakes respectively. Scenarios 7 and 8 reflect potential damage due to an earthquake similar to the Acambay earthquake $\left(M_{w} 6.9\right)$ that took place on 19 November 1912 (Singh et al. 2011) at distances of 80 and $40 \mathrm{~km}$ from CDMX (Online Resource 1). Details about the procedures to develop and the results from these scenarios will be presented in subsequent publications.

\section{Discussion and Conclusions}

In general, there are three phases to mitigate and manage risk: 1) Assessment and analysis; 2) Implementation of mitigation and preventive actions based on the knowledge of the spatial distribution of risk; 3) Design of short and long-term plans designed to reduce the social construction of risk (public policies, land-use planning, environmental restoration, etc.). The objective of this paper is to present a tool developed to assess the level and the spatial distribution of risk to subsidence, floods, earthquakes, volcanic eruptions, forest fires and landslides in CDMX. Our results are a contribution to the first phase of risk management. Our main goal is for this Atlas to provide hard evidence to local authorities and citizens of CDMX to develop preventive actions and mitigation procedures and plans, that allow a complex and highly exposed urban environment like Mexico City to reduce the impact of future disasters.

The main functions of this tool are:

- To provide decision and policy makers with appropriate risk information to strengthen their capacity to develop risk management strategies.

- To allow the general public, local authorities, researchers, experts, media, etc., to:

- Report the results of particular disasters 
- Interactively view and retrieve different hazard, social vulnerability, and risk maps at the CDMX level.

- View and retrieve the maps of exposed elements to the different hazards analyzed, including both, population and infrastructure.

- Develop local case studies of social and structural vulnerabilities and risk for specific hazards.

- A catalyst for a holistic approach aimed at making CDMX a more resilient community.

The findings found in this study also provide elements for the development of early warning systems. Also, our results point out areas where the relocation of population exposed to very high levels of natural hazards may be considered. Clearly, a complete analysis of the risk posed by man-made hazards (explosions, spills, etc.) and sanitaryecological hazards (soil and air pollution, etc.) need be considered in the future.

\section{Author's contributions}

D.A. Novelo-Casanova: Design, planning, supervision of the Atlas and estimates of social vulnerability, exposure, and risk; G. Suárez; Design, planning and supervision of the Atlas and estimation of seismic hazard and scenarios; E. Cabral-Cano, E.A. Fernández-Torres, E. Havazli and D. Solano-Rojas: Design, planning and processing of subsidence hazard; O.A. Fuentes-Mariles, E.D. López-Espinosa, and H.L. Morales-Rodríguez: Flood hazard; M.A. Jaimes: Seismic risk and scenarios; A.L. Martin-Del-Pozzo and A. Nieto-Torres: Volcanic hazard and scenarios; S. Rodríguez-Elizarrarás and W.V. Morales-Barrera: Mass Movement Processes hazard; V.M. Velasco-Herrera: Forest fire hazard.

\section{Acknowledgements}

Our sincere gratitude to Aurora Hernández Hernández, Andrea Juárez Sánchez, Patricia Medina Andrade, Ana B. Ponce Pacheco, Alma R. Espinoza Jiménez, Uriel Martínez Ramírez, Guadalupe Hernández Bello, Paola A. Olmedo Velázquez, Omar Huerta Espinoza, Karla E. Escobar Mercado, Magdalena V. Hernández Luna, Diego E. López 
Maldonado, Nuria D. Vargas Huipe, Amalia E. Macías Rojas, Sabrina E. Espinosa Pacheco, Amayrani Martinez Mendoza, Daniel Ruiz Barón, Susana Rodríguez Padilla, Claudia B. López Venegas, Pamela I. Pedroza Rodríguez, Fernando García Yañez, Esteban Lugo Zavala, Jéssica Atilano Pablo, Heber A. Pacheco Silva, Karla P. Sánchez Albizar, Alma E. Macías Rojas, Esteban Lugo Zavala, Sandra K. González Hernández, Brenda A. González Hernández, Mariana Sandoval García, Montserrat Luna Contreras, and Héctor Raúl Estévez Pérez for invaluable support for data acquisition, processing, storage and management, and for logistics coordination in the fieldworks. We thank the civil protection offices of the following CDMX municipalities: Álvaro Obregón, Azcapotzalco, Cuajimalpa, Cuauhtémoc, Gustavo A. Madero, Iztacalco, Iztapalapa, Magdalena Contreras, Miguel Hidalgo, Milpa Alta, Tlahuac, Tlalpan, and Xochimilco for their cooperation during our fieldwork and for providing data for the project. We are grateful to Hugo Delgado Granados, Gerardo A. Galguera Rosas, Vanesa Ayala Perea, and Viviana Torres Valle for their assistance in the administration of the project. We also, acknowledge Enrique Guevara Ortiz, Carlos Valdés González, Oscar Cepeda Ramos, and Leobardo Domínguez Morales of the Centro Nacional de Prevención de Desastres (CENAPRED), for sharing data and for encouraging the development of this research. Data were obtained from the following institutions: Servicio Sismológico Nacional, Instituto Nacional de Estadística y Geografía (INEGI), Secretaría de Comunicaciones y Transporte (SCT), Instituto Federal de Telecomunicaciones, Comisión Nacional del Agua (CONAGUA), Centro de Instrumentación y Registro Sísmico (CIRES), Comisión Nacional Forestal (CONAFOR), Secretaría de Educación Pública (SEP), Secretaría de Desarrollo Económico (SEDECO), Comisión Reguladora de Energía, and Instituto Federal de Telecomunicaciones (IFT). The Secretaría de Educación, Ciencia, Tecnología e Innovación (SECTEI) of CDMX funded this research (Convenio SECITI/112/2017). We also acknowledge the partial support from the National Autonomous University of Mexico under the "Programa de Apoyo a Proyectos de Investigación e Innovación Tecnológica (PAPIIT Projects No. IT102420, IN107321)" and the Consejo Nacional de Ciencia y Tecnología (CONACYT 2017-015955). 


\section{Compliance with ethical standards}

The authors have no conflicts of interest to declare that are relevant to the content of this article.

\section{References}

Abrahamson NA, Silva WJ (1997) Empirical response spectral attenuation relations for shallow crustal earthquakes. Seism Res Let 68: 94-127.

Aguilar J, Juarez H, Ortega R, Iglesias J (1989) The Mexico Earthquake of September 19, 1985Statistics of damage and of retrofitting techniques in reinforced concrete buildings affected by the 1985 earthquake. Earthq Spec 5(1): 145-151

Auvinet G, Méndez E, Juárez, M (2013) Soil fracturing induced by land subsidence in Mexico City. In Proceedings of the 18th International Conference on Soil Mechanics and Geotechnical Engineering, Paris, 2921-2924

Bard PY (1999) Microtremor measurements: a tool for site affects estimation? Effect of Surface Geology on Seismic Motion. Proc. 2nd Internat. Symp, Yokohama, Japan. 1251-1279

Bjerrum L (1963) Allowable Settlement of Structures. Proc European Conference on Soil Mechanic and Foundation Engineering, Wiesbaden, Brighton, England, 135-137

Boyer ER (1975) La gran inundación: vida y sociedad en México (1629-1638), Secretaría de Educación Pública, México, SepSetentas, 218, 151 p.

Buduma N, Locascio N (2017) Fundamentals of Deep Learning: Designing Next-Generation Machine Intelligence Algorithms. O’Reilly Media, Inc

Burland JB, Mair RJ, Standing JR (2004) Ground performance and building response due to tunnelling. In Advances in Geotechnical Engineering: The Skempton conference 291-342

Burrough PA, McDonnell RA (1998) Principles of geographical information systems. Oxford University Press, New York

Cabral-Cano E, Dixon TH, Miralles-Wilhelm F, Díaz-Molina O, Sánchez-Zamora O, Carande RE (2008) Space Geodetic Imaging of Rapid Ground Subsidence in Mexico City. GSA Bull 120: 1556-1566. doi:10.1130/B26001.1

Cabral-Cano E, Solano-Rojas D, Oliver-Cabrera T, Wdowinski S, Chaussard E, Salazar-Tlaczani, L, Cigna F, DeMets C., Pacheco-Martínez J (2015) Satellite geodesy tools for ground subsidence and associated shallow faulting hazard assessment in central Mexico. Proc IAHS 372: 255-260. doi:10.5194/piahs-372-255-2015

Carrillo N (1948) Influence of Artesian Wells on the Sinking of Mexico City. Proc Second International Conference on Soil Mechanics and Foundation Engineering 2: 156-159

Chaussard E, Wdowinski S, Cabral-Cano E, Amelung F (2014) Land subsidence in central Mexico detected by ALOS InSAR time-series. Rem Sens Environ 140: 94-106. doi:10.1016/j.rse.2013.08.038.

Cigna F, Tapete D (2021) Present-day land subsidence rates, surface faulting hazard and risk in Mexico City with 2014-2020 Sentinel-1 IW InSAR. Rem Sens of Environ, 112161. doi:10.1016/j.rse.2020.112161.

Córdova C, Martin-Del-Pozzo AL, López CJ (1994) Paleoland forms and volcanic impact on the environment of Prehistoric Cuicuilco, southern Mexico City. J Archaeol Sci 21: 585-596 
Courtland LM, Connor CB, Connor L, and Bonadonna C (2012) Introducing Geoscience Students to Numerical Modeling of Volcanic Hazards: The example of Tephra2 on VHub.org, Numeracy, 5(2), Article 6.

Crichton D (1999) The risk triangle. In: Ingleton J, Ed, Natural Disaster Management. Tudor Rose 102-103

Cutter SL, Boruff BJ, Shirley WL (2003) Social Vulnerability to Environmental Hazards. Soc Scien Quart 84: 242-261

Damiani ML, Groppelli G, Norini G, Bertino E, Gigliuto A, Nucita A (2006) A lava Flow simulation model for the development of volcanic hazard maps for Mount Etna (Italy). Comput Geosci 32: 512-526

Denis DJ (2020) Univariate, bivariate, and multivariate statistics using R: Quantitative tools for data analysis and data science. Willey Online Library, 2020. Doi: 10.1002/9781119549963

Du Z, Ge L, Ng AH-M, Zhu Q, Zhang Q, Kuang J, Dong Y (2019) Long-term subsidence in Mexico City from 2004 to 2018 revealed by five synthetic aperture radar sensors. Land Deg Develop 30: 1785-1801. doi:10.1002/ldr.3347.

Duchon J (1977) Splines minimizing rotation invariant semi-norms in Sobolev spaces. In: Constructive Theory of Functions of Several Variables, Springer, Berlin, 85-100, doi:10.1007/BFb0086566

Espinosa Aranda, JM, Jiménez A, Ibarrola G, Alcantara F, Aguilar A, Henestroza M, Maldonado S, (1995) Mexico City: Seismic Alert System. Seismol Res Lett 66: 42-53

Fernández-Torres E, Cabral-Cano E, Solano-Rojas D, Havazli E, Salazar-Tlaczani L (2020) Land Subsidence risk maps and InSAR based angular distortion structural vulnerability assessment: an example in Mexico City. Proc Int Assoc Hydrol Sci, Copernicus GmbH 382: 583-587. doi:https://doi.org/10.5194/piahs-382-583-2020

Ferrari L, Orozco-Esquivel T, Manea V, Manea M (2012) The dynamic history of the TransMexican Volcanic Belt and the Mexico subduction zone. Tectonophysics 522: 122-149

Flores T, Camacho H (1922) Terremoto Mexicano del 3 de enero de 1920. Instituto Geológico Mexicano, Boletín 38. http:/bcct.unam.mx/bogeolpdf/geo38/

Galloway DL, Burbey TJ (2011) Review: Regional land subsidence accompanying groundwater extraction. Hydrogeology, 19: 1459-1486. doi:10.1007/s10040-011-0775-5

García-Acosta V (2006) Risks and Disasters in the History of the Mexico City Basin: are they climatic or social. Med Hist J, 10, 127-142. doi.org/10.1177/097194580701000205

García-Acosta V, Suárez G (1996). Los sismos en la historia de México, tomo I. Universidad Nacional Autónoma de México/Centro de Investigaciones y Estudios Superiores en Antropología Social. Fondo de Cultura Económica, 719

García-Palomo A, Carlos-Valerio V, López-Miguel C, Galván-García, Concha-Dimas A (2006) Landslide inventory map of Guadalupe Range, north of the Mexico Basin. Bol. Soc. Geol Mex 58. doi.org/10.18268/bsgm2006v58n2a2

Gayol R (1925) Estudio de las perturbaciones que en el fondo de la Ciudad de México ha producido el drenaje de las aguas del subsuelo, por las obras del desaguie y rectificación de los errores a que ha dado lugar una incorrecta interpretación de los efectos producidos. Revista Mexicana de Ingeniería y Arquitectura, 3: 96-132

Gencer EA (2013) Natural disasters, urban vulnerability, and risk management: a theoretical overview. In: Gencer E (ed) The Interplay between Urban Development, Vulnerability, and Risk Management. Springer, Heidelberg

Gobierno del Distrito Federal (2004) Normas técnicas complementarias para diseño y construcción de cimentaciones. Gaceta Oficial del Distrito Federal, v. II, 103-BIS, 11-39 
Goel MK (2011) Runoff Coefficient. In: Singh V.P., Singh P., Haritashya UK (eds) Encyclopedia of Snow, Ice and Glaciers. Encyclopedia of Earth Sciences Series. Springer, Dordrecht. https://doi.org/10.1007/978-90-481-2642-2_456

Herrera G, Ezquerro P, Tomás R., Béjar-Pizarro M, López-Vinielles J, Rossi M, Mateos RM, Carreón-Freyre D, Lambert J, Teatini P, Cabral-Cano E, Erkens G, Galloway D, Hung WC, Kakar N, Sneed M, Tosi L, Wang H, Ye S (2021) Global threats of a silent hazard: land subsidence due to groundwater extraction. Science 371: 34-36. doi.org/10.1126/science.abb8549.

Hoberman L (1974) Bureaucracy and disaster: Mexico City and the flood of 1629. J Lat Am Stu, 6: $211-230$

Hooper, DM (1995) Computer-simulation models of scoria cone degradation in the Colima and Michoacán-Guanajuato Volcanic Field, México. Geofis Int 34: 321-340

Jaimes MA, García-Soto AD (2020) Ground-Motion Duration Prediction Model from Recorded Mexican Interplate and Intermediate-Depth Intraslab Earthquakes. Bull. Seismol. Soc. Am. 20 1-16, doi: 10.1785/ 0120200196

Jaimes MA, Reinoso, E, Ordaz M (2006) Comparison of methods to predict response spectra at instrumented sites given the magnitude and distance of an earthquake. J Earthq Eng 10: 887-90, doi: 10.1080/13632460609350622

Jaimes MA, Ramirez-Gaytán A, Reinoso E (2015) Ground-motion prediction model from intermediate-depth intraslab earthquakes at the hill and lake-bed zones of Mexico City. J Earthq Eng 19: 1260-1278, doi: 10.1080/13632469.2015.1025926

Jaimes MA, Niño M (2017) Cost-benefit analysis to assess seismic mitigation options in Mexican public school buildings. Bull. Earthq Eng. 15 (19): 3919-3945, doi: 10.1007/s10518-0170119-5

Jenks GF (1967) The Data Model Concept in Statistical Mapping. Int Yearbook Cartogr 7: 186190

Jiménez-Espinoza M (1996) Programa Ax. Área de Riesgos Hidrometeorológicos. Centro Nacional de Prevención de Desastres. México

Instituto Nacional de Estadística, Geografía e Informática (National Institute of Statistics and Geography): Censo de Población y Vivienda [Census of Population and Housing 2010] (https://www.inegi.org.mx/programas/ccpv/2010/)

Lermo J, Chávez-García FJ (1994) Site effect evaluation at Mexico City: dominant period and relative amplification from strong motion and microtremor records. Soil Dyn Earthq Eng $13: 413-423$

Levi E (1990) History of the drainage of Mexico City. Int J Wat Res Develop 6. https://doi.org/10.1080/07900629008722472

López-Quiroz, P, Doin M-P, Tupin F, Briole P, Nicolas J-M (2009) Time series analysis of Mexico City subsidence constrained by radar interferometry. J App Geophys 69: 1-15. doi:10.1016/j.jappgeo.2009.02.006.

Maloof MA (2005) Machine learning and data mining for computer security: Methods and applications. Advanced Information and Knowledge Processing, Springer 2005

Martin-Del-Pozzo AL (1982) Monogenetic volcanism in Sierra Chichinautzin, Mexico. Bull. Volcanol 45: 9-24

Martin-Del-Pozzo AL, Córdova C, Lopez J (1997) Volcanic impact on the southern basin of Mexico during the Holocene. Quat Int 43: 181-190

Meyerhof GG (1956) Penetration tests and bearing capacity of cohesionless Soils: J Soil Mech and Found Div 82: 1-19 
Mossoux S, Saey M, Bartolini S, Poppe S, Canters F, Kervyn M (2016) Q-LAVHA: a flexible GIS plugin to simulate lava flows. Comput Geosci 97: 98-109. doi:10.1016/j.cageo.2016.09.003

Nakamura Y (1989) A method for dynamic characteristics estimation of subsurface using microtremor on the ground surface. Rail Tech Res Rep 3025-3033

Nieto-Torres A, Martin-Del-Pozzo AL (2019) Spatio-temporal hazard assessment of a monogenetic volcanic field, near México City. J Volcan Geother Res 371: 46-58 doi: 0.1016/j.jvolgeores.2019.01.006

Nieto Torres A (2020) Evaluación del riesgo asociado al vulcanismo monogenético hacia la Ciudad de México. PhD Thesis, Earth Sciences, Universidad Nacional Autónoma de México

Ordaz M, Singh SK (1992) Source spectra and spectral attenuation of seismic waves from Mexican earthquakes, and evidence of amplification in the hill zone of Mexico City. Bull Seismol Soc Am 82:24-43

Osmanoglu B, Dixon TH, Wdowinski S, Cabral-Cano E, Jiang Y (2011). Mexico City subsidence observed with persistent scatterer InSAR. Int J App Earth Obs and Geoinformation 13: 112. dpi:10.1016/j.jag.2010.05.009

Pardo M, Suárez G (1995) Shape of the subducted Rivera and Cocos plates in southern Mexico: Seismic and tectonic implications. J Geophys Res: Solid Earth (1978-2012), 100: 1235712373

Rashed T, Weeks J (2003) Assessing vulnerability to earthquake hazards through spatial multicriteria analysis of urban areas. Int J Geo-Inf 17:47-576

Ricceri G, Soranzo M (1985) An analysis on allowable settlement of structures. Riv Ital Geotec, 177-188

Rosen PA, Gurrola E, Sacco GF (2012) The InSAR scientific computing environment, Proc 9th European Conference on Synthetic Aperture Radar, 730-733

Saaty RW (1980) The Analytic Hierarchy Process, New York: McGraw Hill, Revised editions, Paperback Pittsburg: RWS Publications.

Rosenblueth E, Arciniega A (1992) Response spectral ratios. Earthq Eng Struct Dyn 21:483-492

Rosenblueth E, Meli R (1986) The 1985 Mexico earthquake. Concrete international, 8(5), 23-34

Saaty RW (1987) The Analytic Hierarchy Process-What it is and how it is used. Matem Model 9: $161-176$

Santoyo E, Ovando E, Mooser F, León-Plata E (2005) Síntesis Geotécnica de la Cuenca del Valle de México, TGC Ediciones, Ciudad de México, Mexico, 171pp

Scaletti Cárdenas A (2018) Capital Disasters and Suspended Moves: Mexico (1629) and Lima (1746), Quiroga, 14: 114-123

Siebe C (2000). Age and archaeological implications of Xitle volcano, southwestern Basin of Mexico-City. J Volcan Geother Res 104(1-4): 45-64

Siebe C, Rodríguez-Lara V, Schaaf P, Abrams M (2004) Radiocarbon ages of Holocene Pelado, Guespalapa, and Chichinautzin scoria cones, south of Mexico City: implications for archaeology and future hazards. Bull Volcan, 66: 203-225

Singh SK, Iglesias A, Ordaz M, Pérez-Campos X, Quintanar L (2011) Estimation of Ground Motion in Mexico City from a Repeat of the M 7.0 Acambay Earthquake of 1912. Bull Seism Soc Am, 101: 5, 2015-2028. doi.org/10.1785/0120100317

Skempton AW, Macdonald DH (1956) The allowable settlements of buildings. Proc Inst Civ Eng, London, 50: 727-768. doi:10.1680/ipeds.1956.12202

Solano-Rojas D, Wdowinski S, Cabral-Cano E, Osmanoğlu B (2020) Detecting differential ground displacements of civil structures in fast-subsiding metropolises with interferometric SAR 
and band-pass filtering. Scientific Reports 10: 15460. https://doi.org/10.1038/s41598-02072293-Z

Song, Y, Gong J, Niu L, Li Y, Jiang Y, Zhang W, Cui T (2013) A grid-based spatial data model for the simulation and analysis of individual behaviours in micro-spatial environments. Simul. Model. Pract. Theory 38: 58-68

Sosa-Rodríguez FS (2010) Impacts of Water-management Decisions on the Survival of a City: From Ancient Tenochtitlan to Modern Mexico City. Wat Res Develop 26: 675-687

Stone, WC, Yokel, FY, Celebi M, Hanks T, Leyendecker EV (1987) Engineering aspects of the September 19, 1985 Mexico earthquake. NBS Building Science Series, 165, 207

Suárez G, Espinosa-Aranda JM, Cuellar A, Ibarrola G, García A, Zavala M, Maldonado S, Islas R, (2018) A dedicated Seismic Early Warning Network: The Mexican Seismic Alert System (SASMEX). Seism Res Lett, 89 (2A): 382-391. doi: 10.1785/0220170184

Suárez G, Novelo-Casanova, DA (2018) A Pioneering Aftershock Study of the Destructive 4 January 1920 Jalapa, Mexico, Earthquake. Seism Res Lett. doi: 10.1785/0220180150

Suárez G, Novelo, D, Mansilla E (2009) Performance Evaluation of the Seismic Alert System (SAS) in Mexico City: A Seismological and Social Perspective. Seism. Res. Lett., 80: 707716

UNAM Seismology Group (1986) The September 1985 Michoacan earthquakes: Aftershock distribution and history of rupture. Geophys Res Lett 13:573-576

United Nations (2016) The World's Cities in 2016. Publishing PhysicsWeb. http://www.un.org/en/development/desa/population/publications/pdf/urbanization/the_worl ds_cities_in_2016_data_booklet.pdf.

Urbina F, Camacho H (1913) La zona megaséismica Acambay-Tixmadeje, estado de México: conmovida el 19 de noviembre de 1912 (Vol. 32). Imprenta y fototipia de la Secretaría de fomento, Mexico

Wahls HE (1981) Tolerable settlement of buildings. J. Geotech. Eng, 109: 1495-1496. doi:10.1061/(ASCE)0733-9410(1983)109:11(1495.2).

Wood CA (1980) Morphometric evolution of cinder cones. J. Volcanol. Geotherm. Res. 7: 387413

Yunjun Z, Fattahi H ,Amelung F (2019) Small baseline InSAR time series analysis: Unwrapping error correction and noise reduction: Comput \& Geosc 133: 104331, doi:10.1016/j.cageo.2019.104331 


\section{FIGURE CAPTIONS}

Fig. 1 Seismic microzonation of CDMX. Data from the Accelerographic Network of Mexico City (RACM) and work from previous studies. The station locations of new measurements are indicated by yellow and green triangles, respectively.

Fig. 2 Seismic source regionalization used in the estimation of seismic hazard.

Fig. 3 Seismic hazard for peak ground acceleration (PGA) (g) for return periods of 20, 125, 150 and 475 years.

Fig. 4 a) Zones A, B, and C indicate the more probable sites where a new volcano could erupt in the Younger Chichinautzin Monogenetic Field (YCMF). The spatial probability of hosting a future eruption in the YCMF is also indicated; b) Expected lava flows scenarios for zones A, B, and C (see text). From Nieto-Torres and MartinDel-Pozzo (2019) and Nieto-Torres (2020).

Fig. 5 Spatial distribution of: a) Subsidence rate; b) Horizontal subsidence gradient; c) Angular distortion for the CDMX.

Fig. 6 a) Map of the tributary stream areas in the Metropolitan Zone of the Basin of Mexico (MZBM); b) Geometry of the hemisphere containing the volume of water within each tributary area.

Fig. 7 Flood hazard estimation for a return period of 10 years in the CDMX.

Fig. 8 a) Probability of forest fires occurrence in CDMX during the rain season for the following five years (2021-2025); b) Same as a) for the dry season; c) Forest fire forecast up to year 2028. Red dots are the annual number of forest fires reported by the Mexican National Forest Commission until 2020. From 2020 to 2028 forest fires are forecast using our model. The blue line approximates the data's tendency. The vertical red dashed line separates the historical from the forecast data. The horizontal solid and dashed lines indicate the mean and standard deviation, respectively. The shadowed area outlines the $95 \%$ confidence interval. 
Fig. 9 Inventory of Mass Movement Processes (purple and gray solid circles) and spatial distribution of landslide susceptibility.

Fig. 10 Spatial distribution of social vulnerability in CDMX.

Fig. 11 Schematic representation of risk estimation.

Fig. 12 Social risk in the CDMX for: a) subsidence; and b) an earthquake with a return period of 125 years.

\section{ONLINE RESOURCE CAPTION}

Online Resource 1. Maps in PDF format of the Risk Atlas of Mexico City, Mexico, generated or updated during the course of this project. 


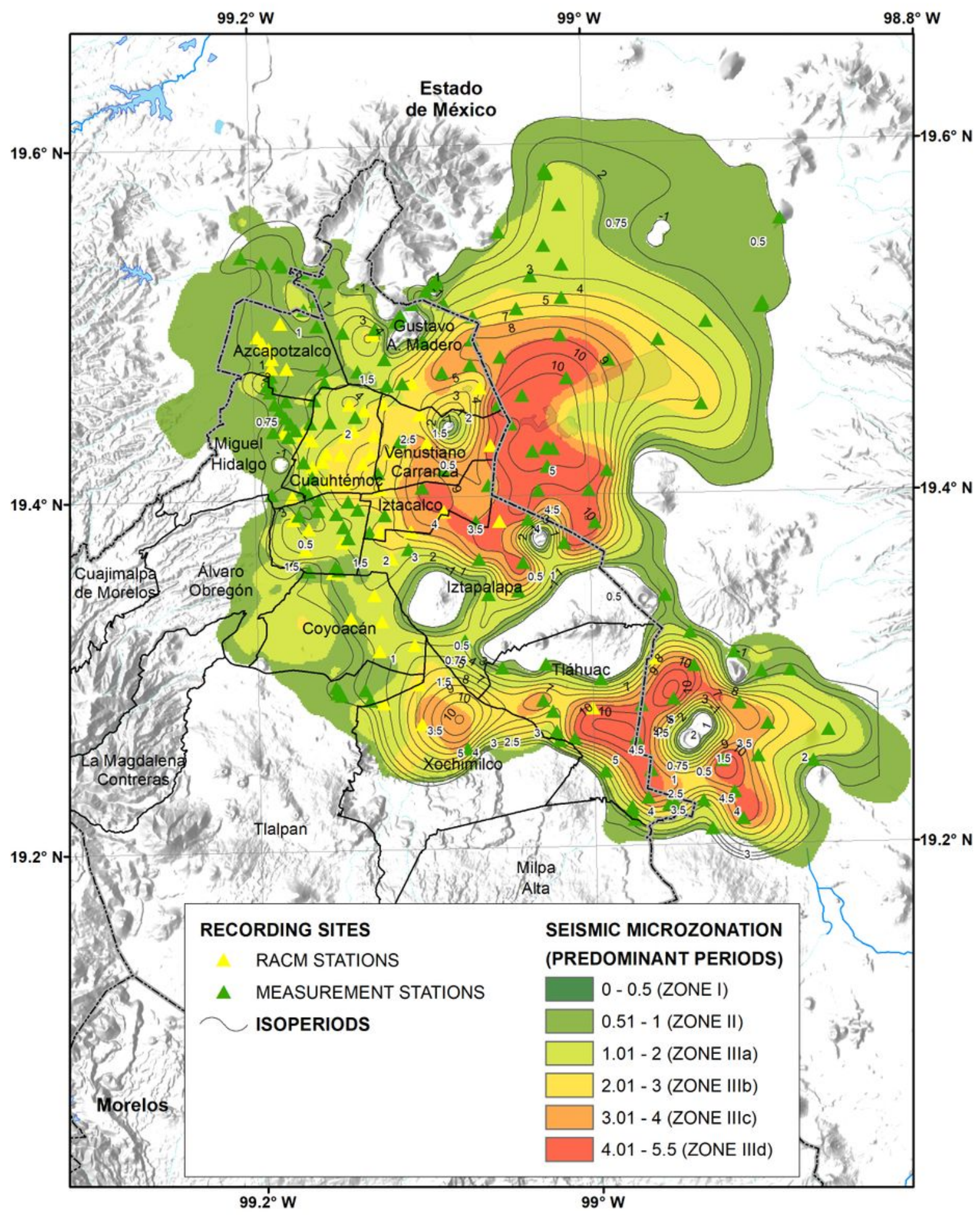

\section{Figure 1}

Seismic microzonation of CDMX. Data from the Accelerographic Network of Mexico City (RACM) and work from previous studies. The station locations of new measurements are indicated by yellow and green triangles, respectively. Note: The designations employed and the presentation of the material on 
this map do not imply the expression of any opinion whatsoever on the part of Research Square concerning the legal status of any country, territory, city or area or of its authorities, or concerning the delimitation of its frontiers or boundaries. This map has been provided by the authors.

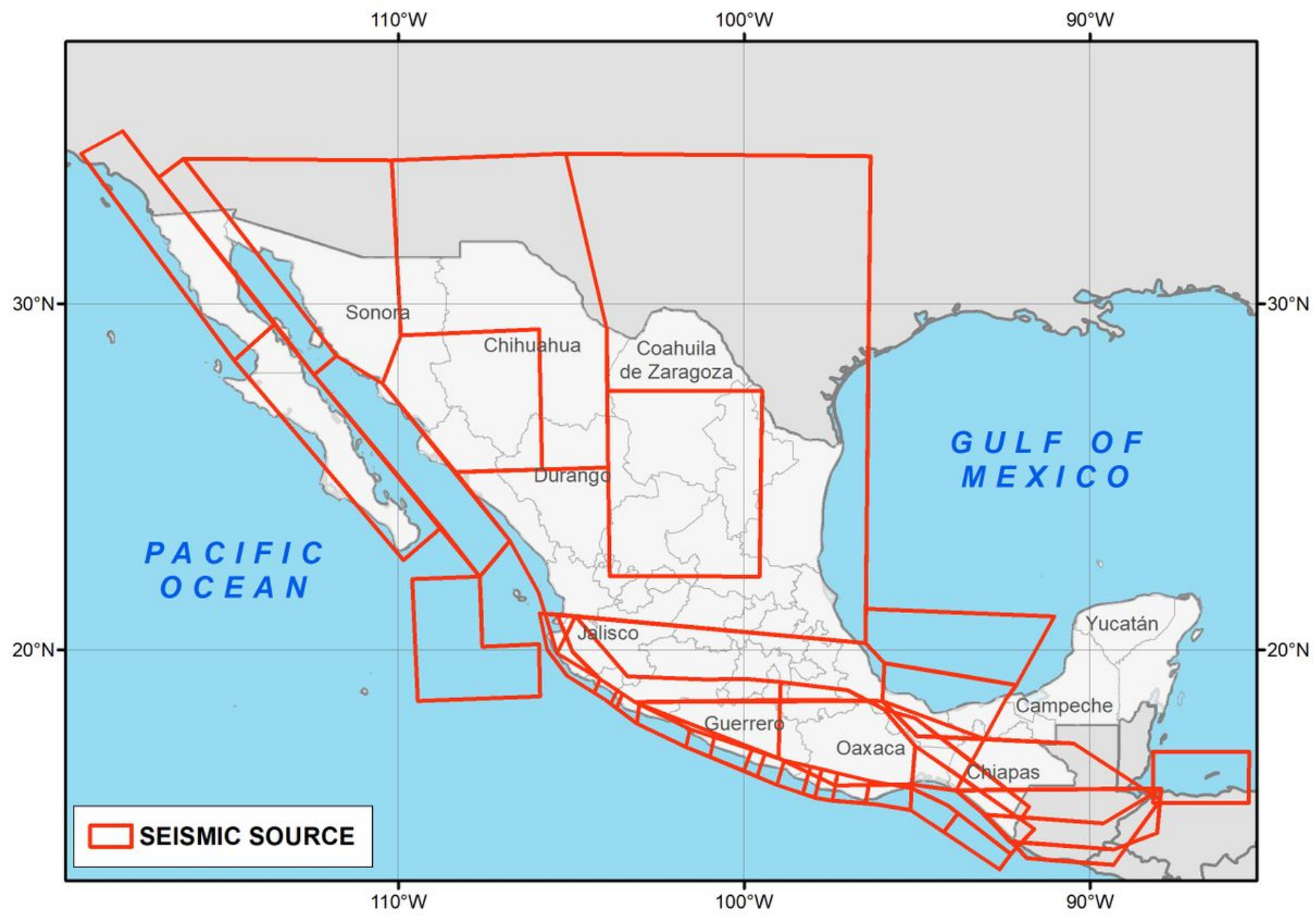

Figure 2

Seismic source regionalization used in the estimation of seismic hazard. Note: The designations employed and the presentation of the material on this map do not imply the expression of any opinion whatsoever on the part of Research Square concerning the legal status of any country, territory, city or area or of its authorities, or concerning the delimitation of its frontiers or boundaries. This map has been provided by the authors. 


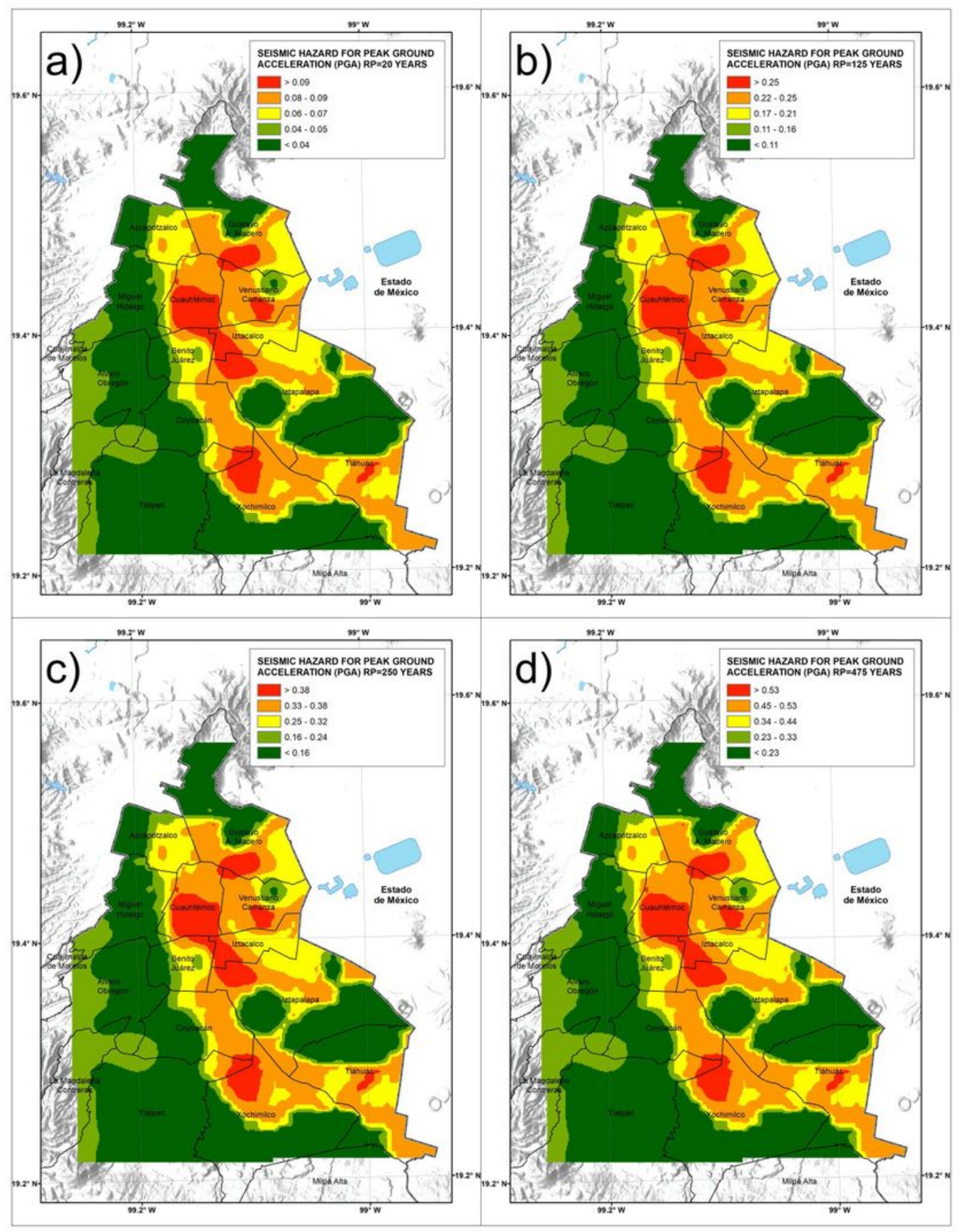

\section{Figure 3}

Seismic hazard for peak ground acceleration (PGA) (g) for return periods of 20, 125, 150 and 475 years. Note: The designations employed and the presentation of the material on this map do not imply the expression of any opinion whatsoever on the part of Research Square concerning the legal status of any country, territory, city or area or of its authorities, or concerning the delimitation of its frontiers or boundaries. This map has been provided by the authors. 


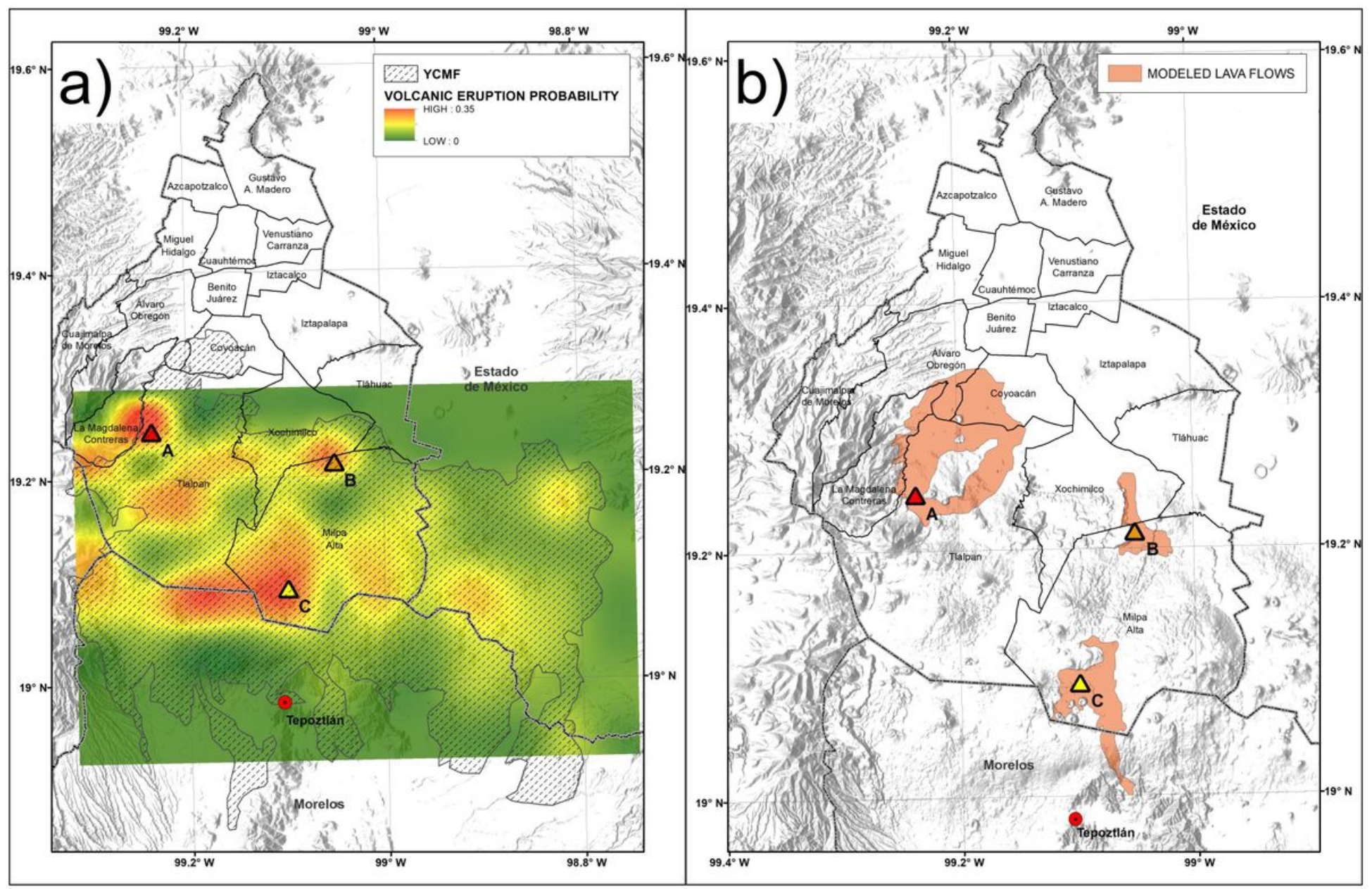

Figure 4

a) Zones $\mathrm{A}, \mathrm{B}$, and $\mathrm{C}$ indicate the more probable sites where a new volcano could erupt in the Younger Chichinautzin Monogenetic Field (YCMF). The spatial probability of hosting a future eruption in the YCMF is also indicated; b) Expected lava flows scenarios for zones A, B, and C (see text). From Nieto-Torres and Martin-Del-Pozzo (2019) and Nieto-Torres (2020). Note: The designations employed and the presentation of the material on this map do not imply the expression of any opinion whatsoever on the part of Research Square concerning the legal status of any country, territory, city or area or of its authorities, or concerning the delimitation of its frontiers or boundaries. This map has been provided by the authors. 


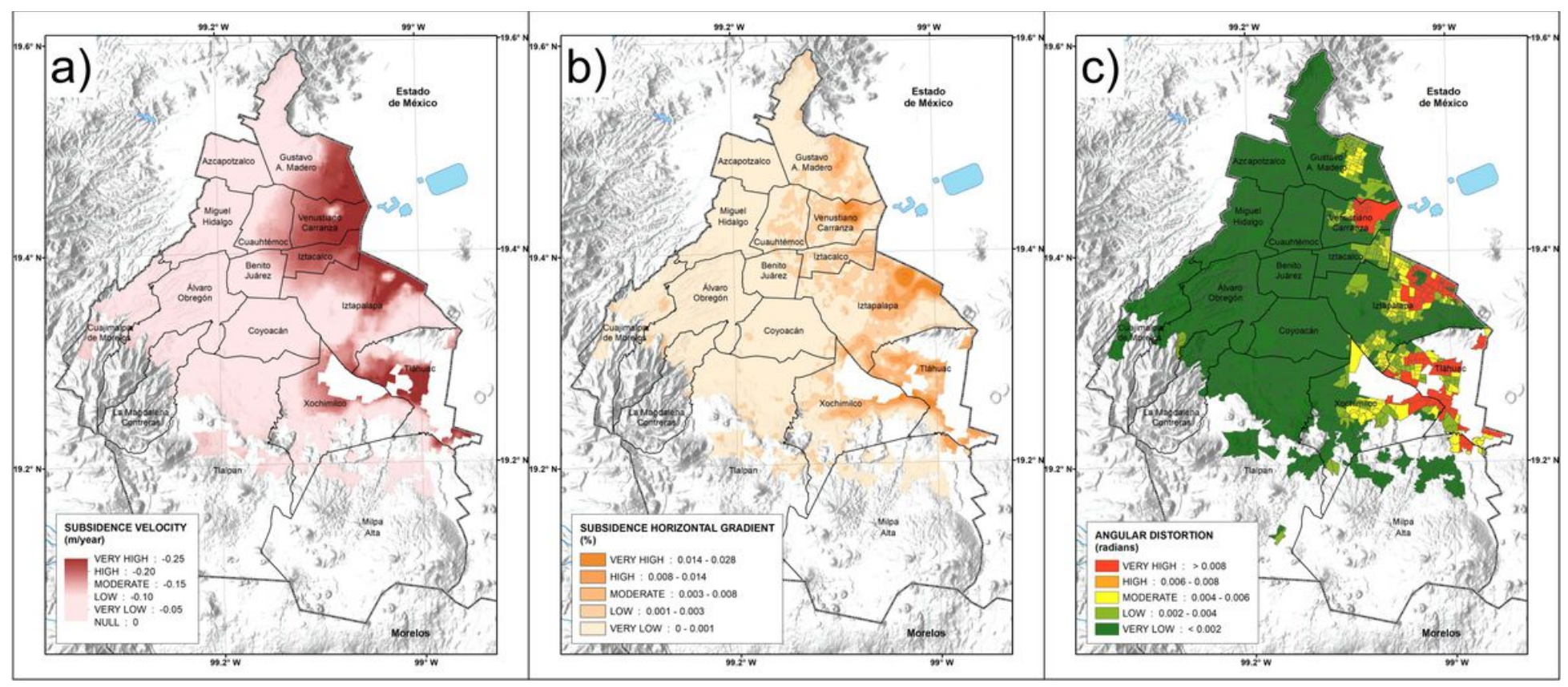

\section{Figure 5}

Spatial distribution of: a) Subsidence rate; b) Horizontal subsidence gradient; c) Angular distortion for the CDMX. Note: The designations employed and the presentation of the material on this map do not imply the expression of any opinion whatsoever on the part of Research Square concerning the legal status of any country, territory, city or area or of its authorities, or concerning the delimitation of its frontiers or boundaries. This map has been provided by the authors. 


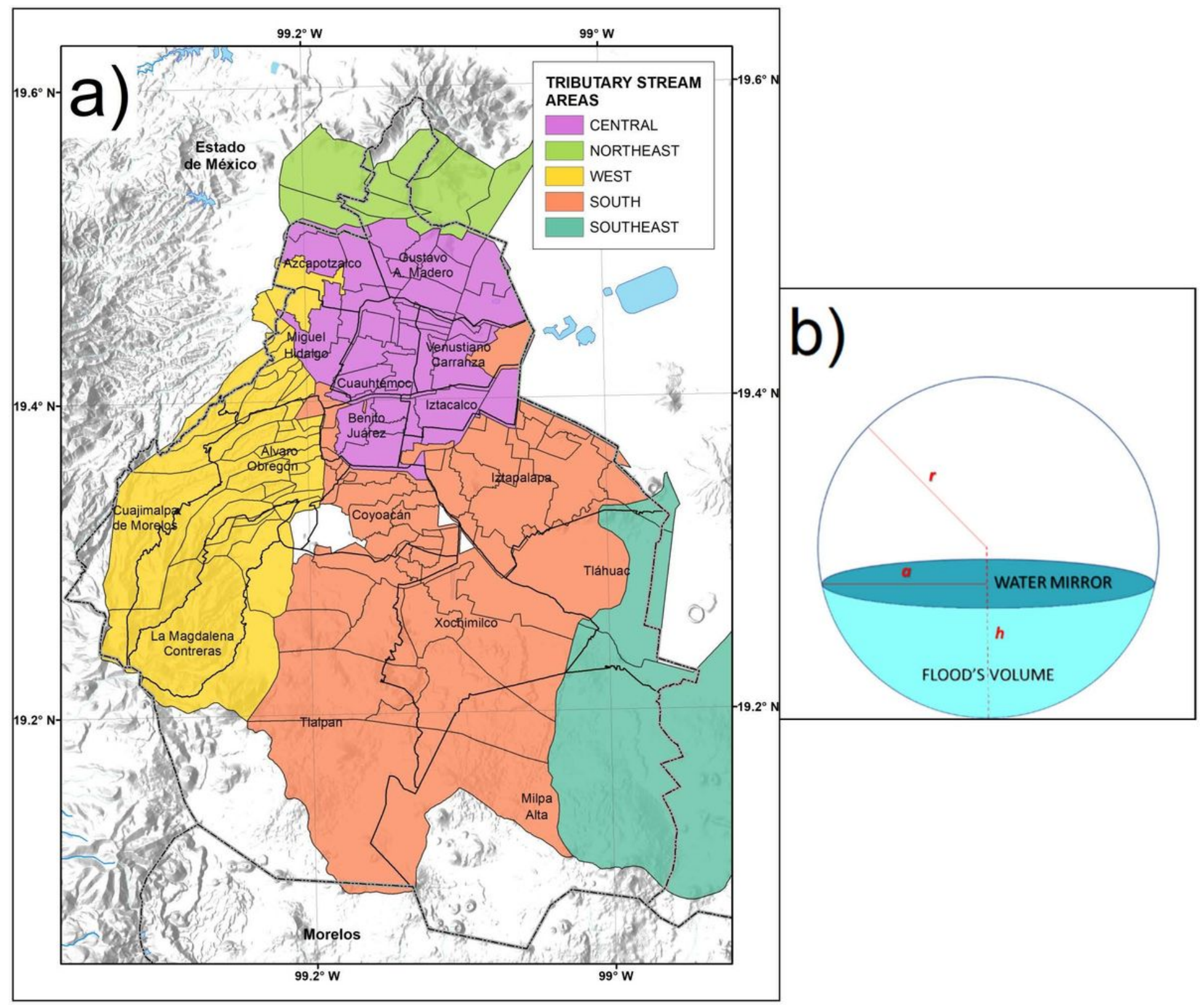

Figure 6

a) Map of the tributary stream areas in the Metropolitan Zone of the Basin of Mexico (MZBM); b) Geometry of the hemisphere containing the volume of water within each tributary area. Note: The designations employed and the presentation of the material on this map do not imply the expression of any opinion whatsoever on the part of Research Square concerning the legal status of any country, territory, city or area or of its authorities, or concerning the delimitation of its frontiers or boundaries. This map has been provided by the authors. 

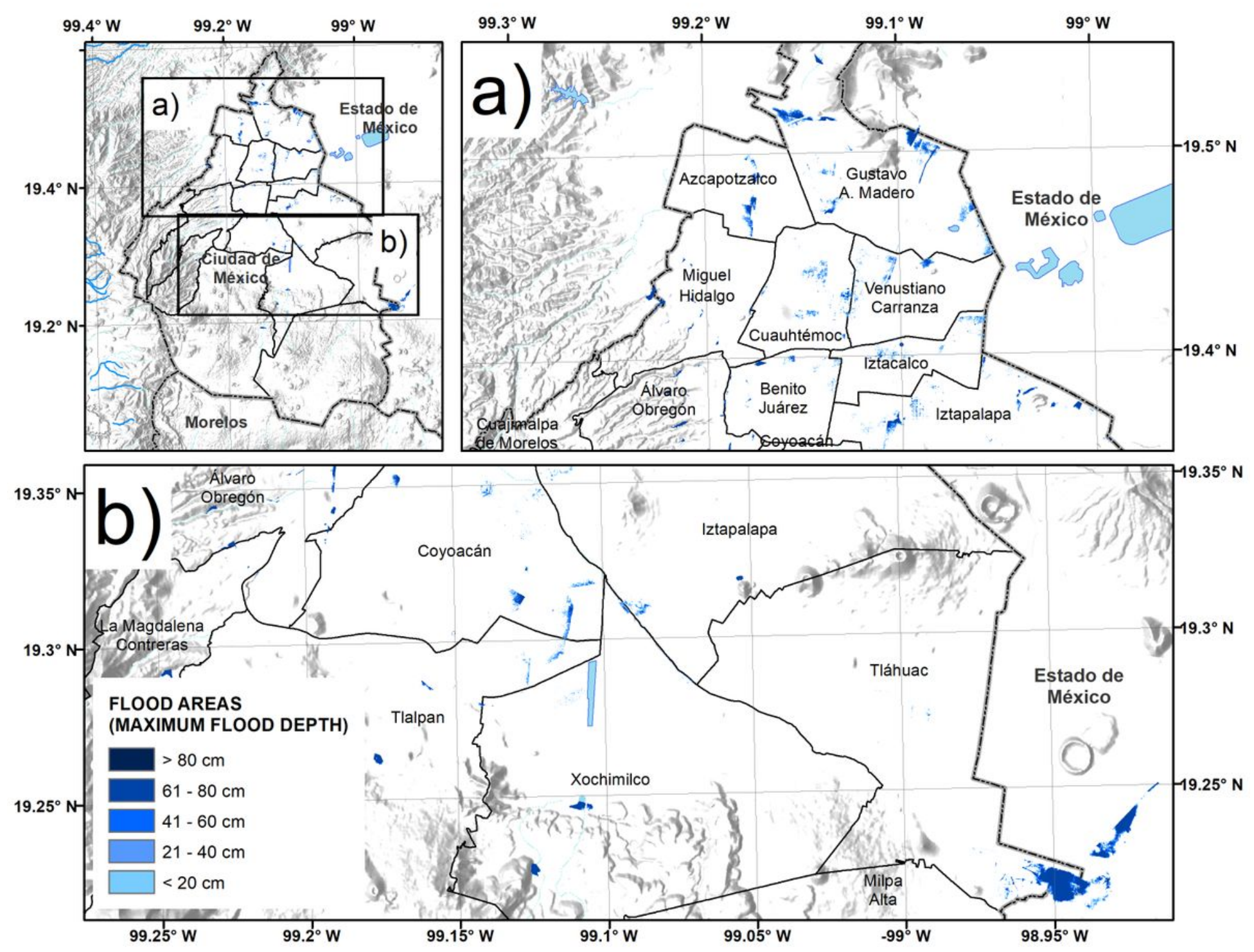

Figure 7

Flood hazard estimation for a return period of 10 years in the CDMX. Note: The designations employed and the presentation of the material on this map do not imply the expression of any opinion whatsoever on the part of Research Square concerning the legal status of any country, territory, city or area or of its authorities, or concerning the delimitation of its frontiers or boundaries. This map has been provided by the authors. 


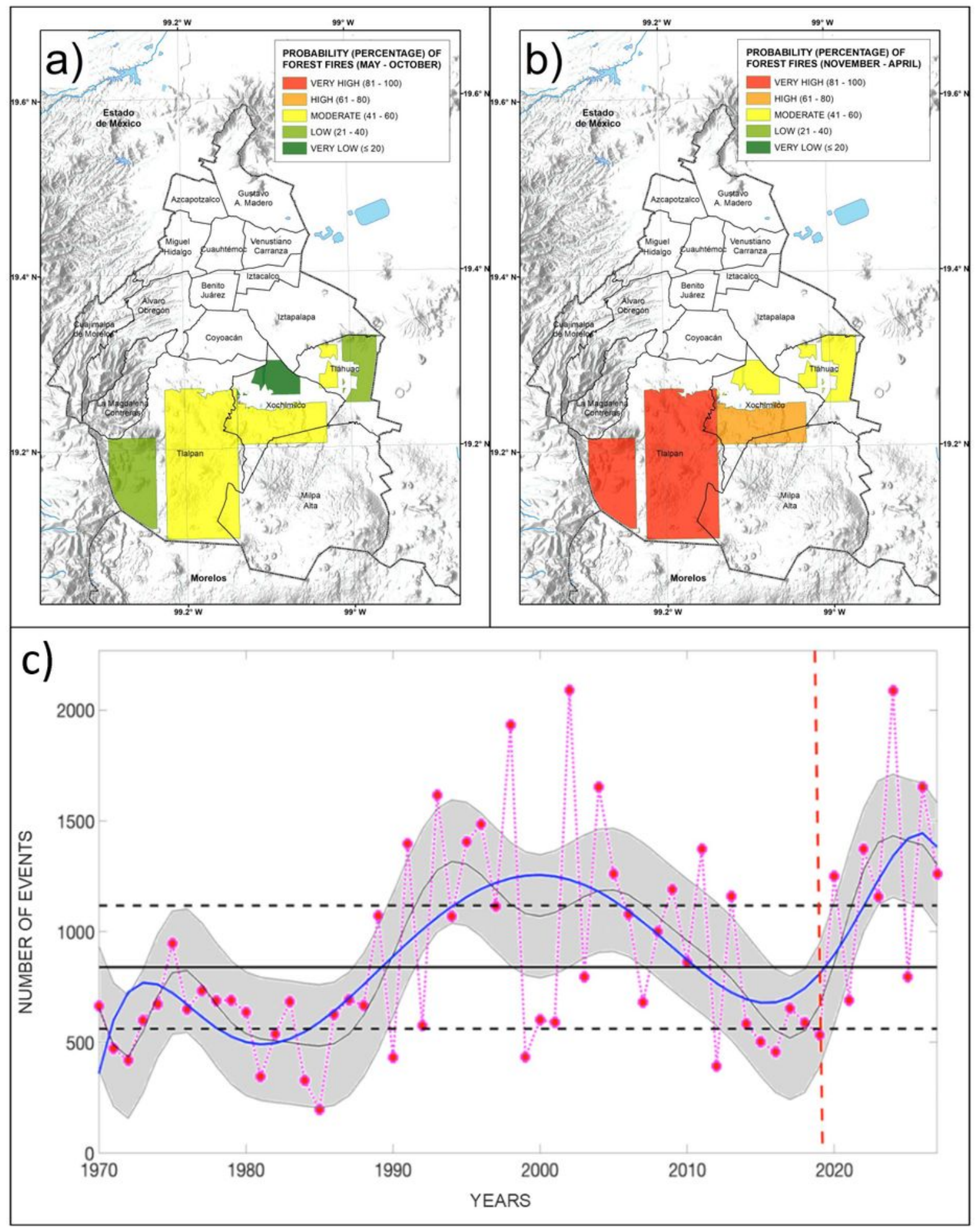

\section{Figure 8}

a) Probability of forest fires occurrence in CDMX during the rain season for the following five years (20212025); b) Same as a) for the dry season; c) Forest fire forecast up to year 2028. Red dots are the annual number of forest fires reported by the Mexican National Forest Commission until 2020. From 2020 to 2028 forest fires are forecast using our model. The blue line approximates the data's tendency. The vertical red dashed line separates the historical from the forecast data. The horizontal solid and dashed 
lines indicate the mean and standard deviation, respectively. The shadowed area outlines the $95 \%$ confidence interval.

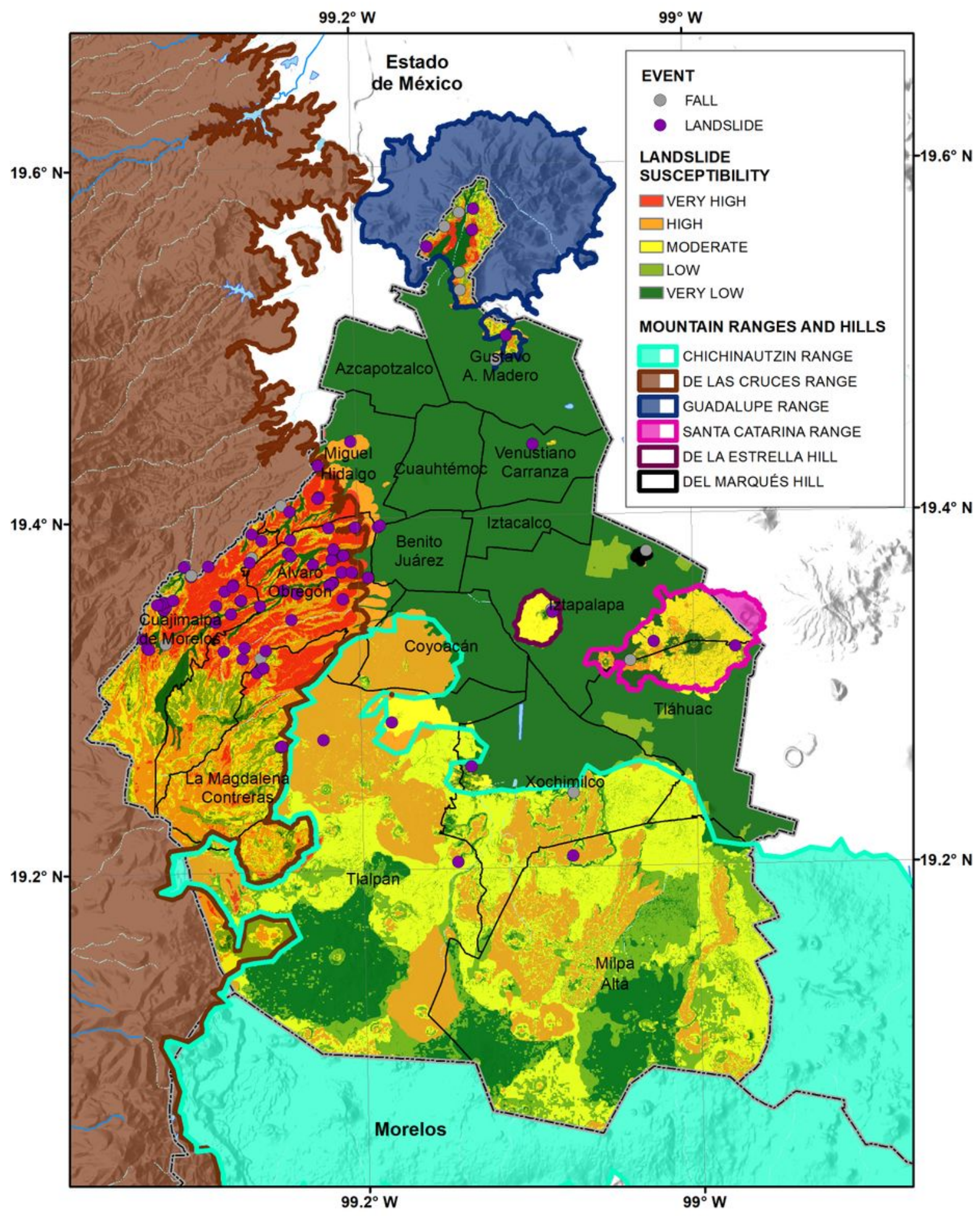

\section{Figure 9}

Inventory of Mass Movement Processes (purple and gray solid circles) and spatial distribution of landslide susceptibility. Note: The designations employed and the presentation of the material on this map do not imply the expression of any opinion whatsoever on the part of Research Square concerning 
the legal status of any country, territory, city or area or of its authorities, or concerning the delimitation of its frontiers or boundaries. This map has been provided by the authors.

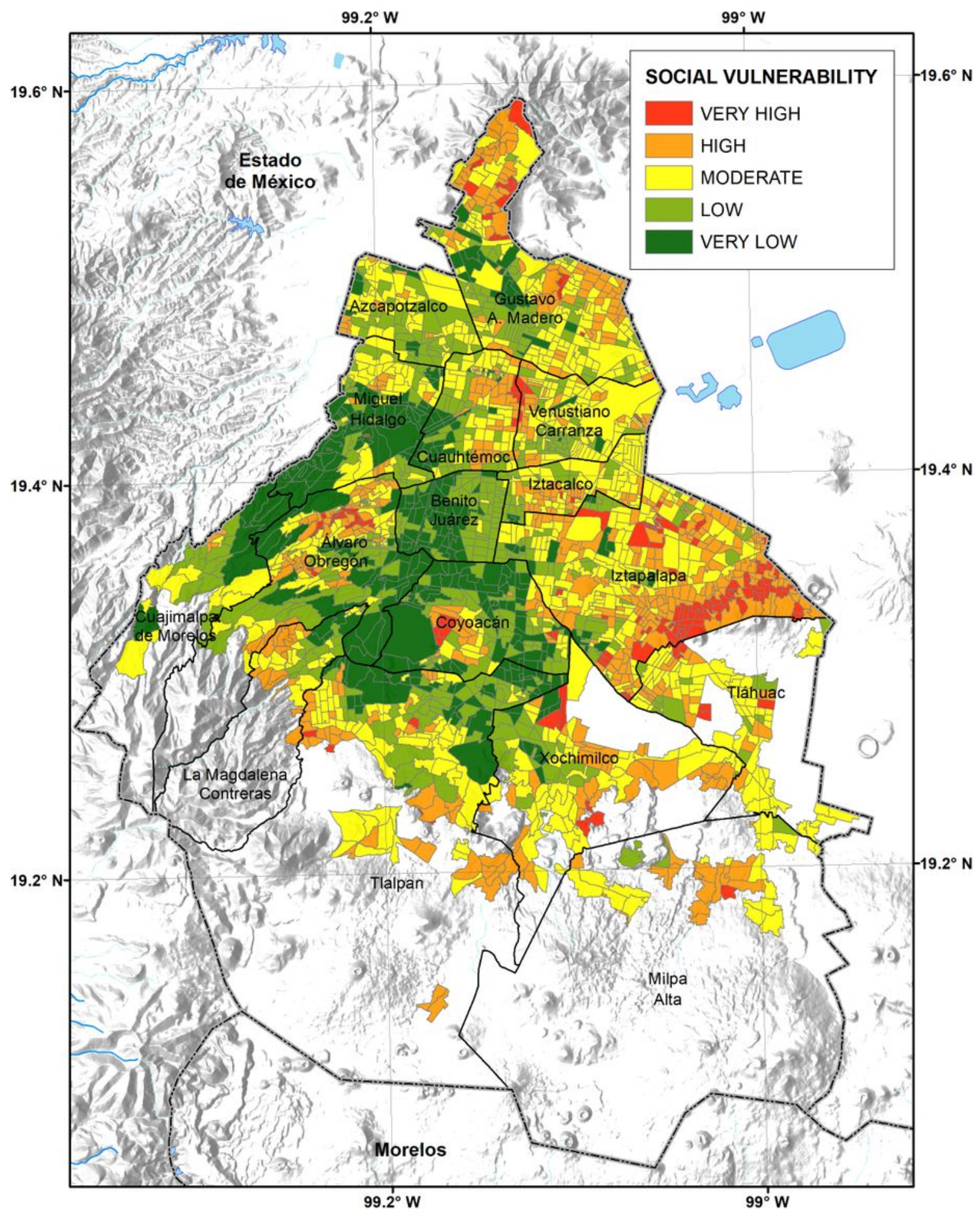

Figure 10

Spatial distribution of social vulnerability in CDMX. Note: The designations employed and the presentation of the material on this map do not imply the expression of any opinion whatsoever on the part of Research Square concerning the legal status of any country, territory, city or area or of its 
authorities, or concerning the delimitation of its frontiers or boundaries. This map has been provided by the authors.

Hazard

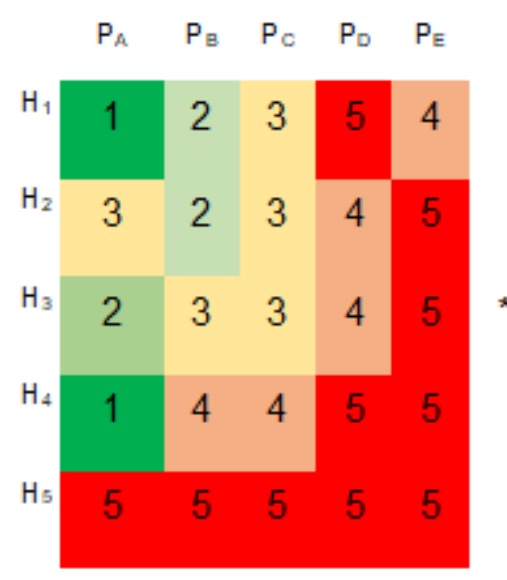

Vulnerability

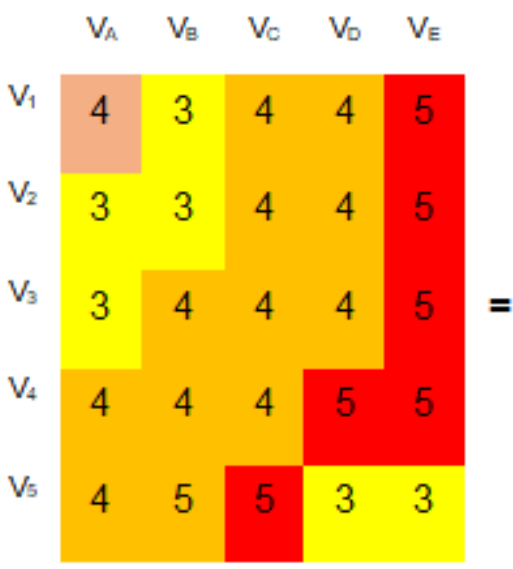

\section{Risk}

\begin{tabular}{l|c|c|c|c|c} 
& $R_{A}$ & $R_{B}$ & $R_{\subset}$ & $R_{\triangleright}$ & $R_{\Xi}$ \\
$R_{1}$ & 4 & 6 & 12 & 20 & 20 \\
$R_{2}$ & 9 & 6 & 12 & 16 & 25 \\
$R_{3}$ & 6 & 12 & 12 & 16 & 25 \\
$R_{4}$ & 4 & 16 & 16 & 25 & 25 \\
$R_{5}$ & 20 & 25 & 25 & 15 & 15
\end{tabular}

\section{Figure 11}

Schematic representation of risk estimation.

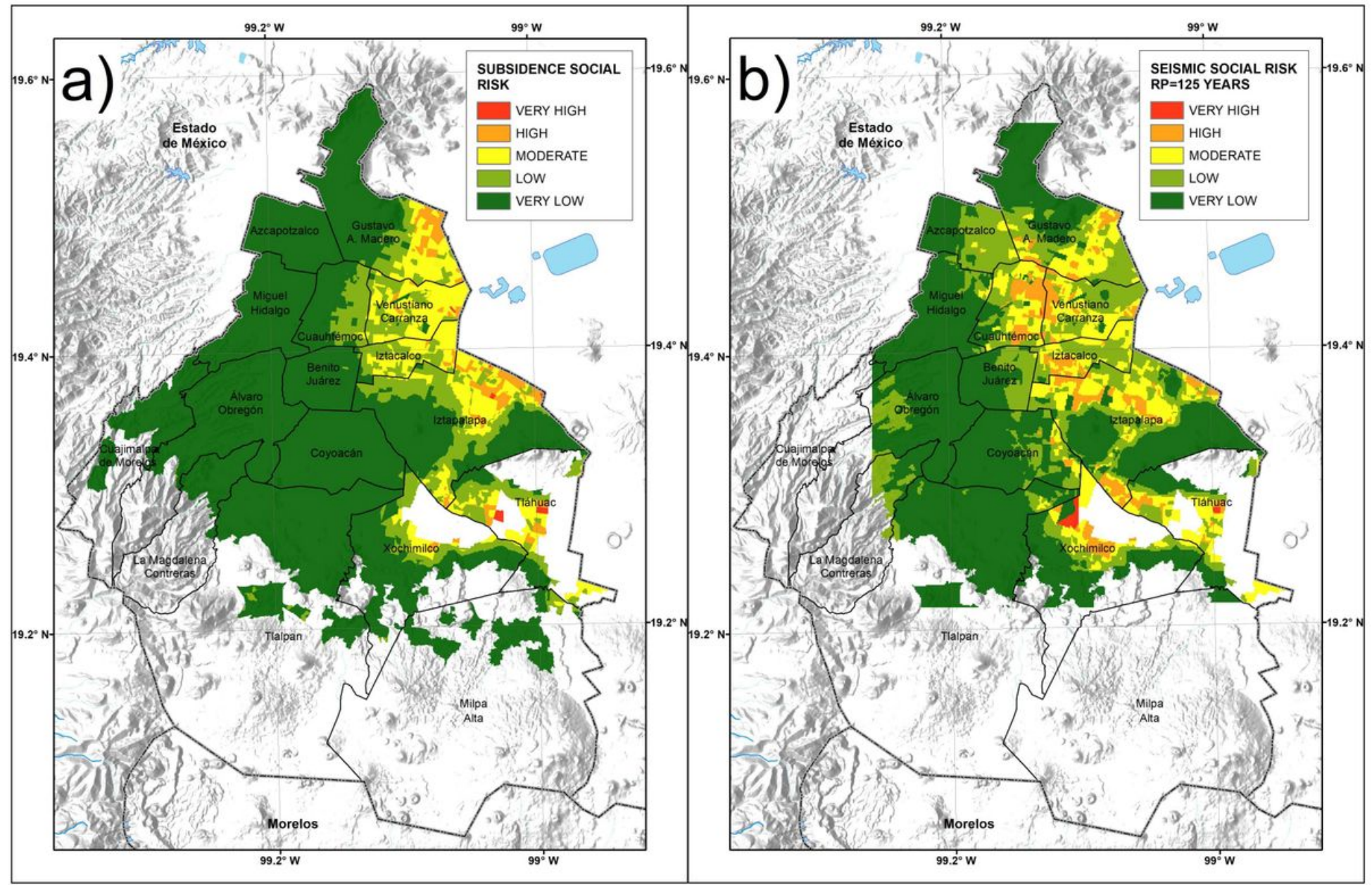

Figure 12 
Social risk in the CDMX for: a) subsidence; and b) an earthquake with a return period of 125 years. Note: The designations employed and the presentation of the material on this map do not imply the expression of any opinion whatsoever on the part of Research Square concerning the legal status of any country, territory, city or area or of its authorities, or concerning the delimitation of its frontiers or boundaries. This map has been provided by the authors.

\section{Supplementary Files}

This is a list of supplementary files associated with this preprint. Click to download.

- OnlineResource1.pdf 